\title{
Land Use Litigation, Federal Jurisdiction, and the Abstention Doctrines
}

\author{
William E. Ryckman, Jr. $†$
}

Litigation concerning the validity or enforceability of public laws regulating the use of private land, generally termed land use litigation, has a distinctly local flavor. The plaintiffs in such higation, whether notivated by private concern or public interest, typically represent highly specific and local interests, and seek correspondingly limited local relief. The defendants' general hoinogeneity-they are usually local officials who are surrogates for the communities they representfurther illustrates the local interests involved in such litigation. Reflecting the fact that unost land use controversies are essentially local in nature, the arenas chosen for such disputes have, until recently, been local foruins.

The land use plaintiff almost invariably turns to the local zoning board or planning commission as the tribunal of first resort. There are two advantages to this approach. First, seeking resolution of a land use dispute at the local admmistrative level inaximizes plaintiff's chances for keeping the contours of the dispute fluid. There is a give-and-take about a variance, special permit, or subdivision approval hearing before a local board that a judicial setting can never reproduce, and in such an atinosphere, practical coinpromises are often achieved. Second, and equally important, is the cost factor. A local board hearing costs relatively little. Even if the parties are represented by counsel, the speed with which a local board hearing can be completed and the decision implemented contrasts dranatically with the delays traditionally associated with litigation. Only idealisin or despair would counsel the average developer to forego the administrative remedy. Whether exhaustion of administrative remedies is a legal imperative, it is in most cases a praginatic one.

Historically, failure of the administrative forum to produce satisfactory results left the landowners with a limited choice of remedies

$\dagger$ Professor of Law, Boston University. B.S. 1956, LL.B. 1958, Indiana University.

1 would like to thank Henry P. Monaghan for his invaluable assistance on the early drafts of this Article, and James A. Henderson, Jr., Robert B. Kent, and Daniel G. MacLeod for their editorial assistance as it took final form. 
and no choice of judicial forums. Plaintiff could pursue a statutorily prescribed judicial review process or seek an extraordinary writ, a declaratory judgment, or injunctive relief, all in the state court system. Typically, the plaintiff did not seriously consider seeking relief in the federal courts. ${ }^{1}$

This tendency for land use plaintiffs to look almost exclusively to state courts lasted until relatively recently. There were various reasons why plaintiffs did not use the federal forum. The jurisdictional amount requirement of 28 U.S.C. section 1331, the statute conferring general federal question jurisdiction, was a barrier in some cases. Land use cases usually involved "property" rights, for which there was no cause of action under 42 U.S.C. section 1983, and no federal jurisdiction under 28 U.S.C. section 1343. Diversity jurisdiction was typically unavailable in land use cases, since both parties were usually local residents.

In those cases in which the existence of a federal question provided jurisdiction, however, the federal forum offered the plaintiff several advantages. Adjudication in federal court theoretically minimizes the possibility of local bias against federal claims, because federal judges are less exposed to local pressures than their state court counterparts, federal juries are selected from wider geographic areas, and the courts of appeal reflect a multistate perspective. ${ }^{2}$ Also, the Federal Rules of Civil Procedure offer procedural advantages to litigants who opt for the federal forum.

It is iromic, however, that plaintiffs have recently begun to turn to the federal forum, considering that state courts have also recently becoine more attractive to plaintiffs. For example, recent cases have held

1. But see Village of Euclid v. Ambler Realty Co., 272 U.S. 365 (1926) (constitutional challenge to general zoning plan denied); Marcus Brown Holding Co. v. Feldınan, 256 U.S. 170 (1921) (constitutional challenge to New York housing law denied); McLarty v. Borough of Ramsey, 270 F.2d 232 (3d Cir. 1959) (dismissal of challenge to use regulations upheld on mootness grounds); Madison v. Reichelt, 267 F.2d 942 (4th Cir. 1959) (per curiam) (relief denied in diversity zoning case); Mestre v. City of Atlanta, 255 F.2d 401 (5th Cir. 1958) (rezoning upheld); Kroeger v. Stahl, 248 F.2d 121 (3d Cir. 1957) (use regulations upheld over commerce clause challenge); Valley View Village, Inc. v. Proffett, 221 F.2d 412 (6th Cir. 1955) (use regulations held to be within inunicipality's power); City of Birmingham v. Monk, 185 F.2d 859 (5th Cir. 1950) (racial zoning held unconstitutional), cert. denied, 341 U.S. 940 (1951); East Coast Luniber Terminal, Inc. v. Town of Babylon, 174 F.2d 106 (2d Cir. 1949) (Pullman abstention held proper in suit seeking mjunctive relief against enforcentent of earth renoval ordinance); City of Miami Beach v. Benhow Realty, Inc., 168 F.2d 378 (5th Cir. 1948) (upholding preliminary rehief against enforcement of noise ordinance); American Wood Prods. Co. v. City of Minneapolis, 35 F.2d 657 (8th Cir. 1929) (use regulations upheld); Village of Univ. Heights v. Cleveland Jewish Orphans' Home, 20 F.2d 743 (6th Cir. 1927) (use regulations held unreasonable as applied); Downham v. City Council, 58 F.2d 784 (E.D. Va. 1932) (use regulations upleld); Morrison v. Pettigrew, 14 F.2d 453 (E.D.N.Y. 1926) (dimeusional regulations in zoning ordinance upleld).

2. See United Steelworkers v. R.H. Bouligny, Inc., 382 U.S. 145, 150 (1965). 
that state courts have permissive concurrent jurisdiction of section 1983 claims, $^{3}$ and attorneys' fees under 42 U.S.C. section 1988 may be awarded to the prevailing party in state court section 1983 suits, perhaps even if the plaintiff prevails on the basis of a state claim. ${ }^{4}$ In addition, unlike the federal courts, most state systems do not pose the substantial threat of denying standing to certain types of plaintiffs. ${ }^{5}$

Nevertheless, since 1960 the situation has changed drainatically. The bulk of land use htigation still takes place in state courts, but plaintiffs no longer ignore the federal forum. ${ }^{6}$ The sheer volume of zoning hitigation inay explain this phenoinenon in part, as might the supposed advantages of the federal forum, including the forum's supposed aloofness from the political and psycliological pressures affectimg state courts. ${ }^{7}$ Perhaps, also, more lawyers today are comfortable litigating in the federal courts than was the case previously. The federal procedures are no longer new and unknown. Also, some attorneys inay well believe that they can enhance their clients' bargaining positions by confronting local land use officials with challenges of constitutional dimension and the specter of federal judicial imtervention.

These ventures into the federal forum liave not been entirely propitious, however. More often than not the federal land use plaintiff loses. Tlie plaintiffs lack standing, in article III or prudential terms, or fail to show "discriminatory intent." They discover that their property has only "diminished" in value and has not been "taken." Tliey learn that a rational basis exists for classifications thought permicious.

Conventional analysis has criticized two aspects of the evolving barriers to successful federal court challenges of land use regulations: (1) the Supreme Court's conservatism regarding taking claims, and, im the land use context, in interpreting constitutional mandates sucl as the first ainendinent, the equal protection clause, and rights of association grounded in substantive due process; ${ }^{8}$ and (2) the Court's position on

3. Maine v. Thiboutot, 100 S. Ct. 2502, 2503 n.1 (1980); Martinez v. California, 444 U.S. 277, 283 n.7 (1980).

4. Maher v. Gagne, 100 S. Ct. $2570,2576 \&$ n. 15 (1980).

5. While there are occasional examples of state courts imposing limitations on standing to maintain land use disputes, they are normally a by-product of the state courts' interpretation of statutory appeals procedures. See, e.g., Circle Lounge \& Grille, Inc. v. Board of Appeal, 324 Mass. 427, 86 N.E.2d 920 (1949) (statutory limitation on the class of aggrieved persons). Where this is not the case, however, state courts seem generally less receptive to judge-inade prudential limitations on standing than are the federal courts. See, e.g., Urban League v. Township of Mahwah, 147 N.J. Super. 28, 370 A.2d 521, petition for cerlif. denied, 74 N.J. 278, 377 A.2d 682 (1977).

6. See Note, Land Use Regulation, the Federal Courts, and the Abstention Doctrine, 89 YALE L.J. 1134, 1145 n.63 (1980).

7. See generally Neuborne, The Myth of Parity, 90 HARv. L. Rev. 1105, 1125 (1977).

8. See Developments in the Law-Zoning, 91 HARv. L. Rev. 1427, 1550-78, 1666-79 (1978). 
the constitutional and prudential limitations on federal judicial power. ${ }^{9}$ Commentators see these developments as portending the federal judiciary's abandonment of an arena of governmental regulation having profound social consequences for racial minorities and the economically disadvantaged. ${ }^{10}$

This Article does not examine the substantive developinents of land use hitigation. Instead, it focuses on the doctrines-primarily Pullman, Burford, and Younger abstention-that limit access to the federal courts in such cases even though claims potentially justiciable in those courts are a substantial component of the plaintiff's complaint. These doctrines are the product of equitable and federalism considerations, and have evoked reams of analysis, mostly hostile. The critics view "Our Federahisin" as an unwarranted retreat from the idea that federal courts should be the primary guardians of federal rights. In particular, Burford and Younger abstention are criticized because they restrict access to the federal courts in important civil rights cases. ${ }^{12}$

Much of the criticism seems misplaced in the land use setting. Acceptance of the propositions that federal courts have a special role to play in the civil rights area, and that land use cases are soinetimes civil rights cases, does not compel the conclusion that any land use controversy that can be cast in civil rights teruns is entitled to vindication in a federal forum. In fact, the essentially local character of these disputes and their potential for resolution on nonconstitutional grounds should inake federal courts wary of assuming the role of a zoning appeals court through the exercise of primary and pendent jurisdiction. ${ }^{13}$ Fed-

9. See Sager, Insular Minorities Unabated: Warth v. Seldin and City of Eastlake v. Forest City Enterprises, Inc., 91 HARv. L. REv. 1373 (1978).

10. See, e.g., Hogue, Eastlake and Arlington Heights: New Hurdles in Regulating Urban Land Use?, 28 CASE W. RES. L. REv. 41 (1977); Mandelker, Racial Discrimination and Exclusionary Zoning: A Perspective on Arlington Heights, 55 Tex. L. REv. 1217 (1977); Sager, supra note 9.

By contrast, where a regulatory scheme implicates an environmental interest, no similar concern is generally expressed, although the regulatory teclinique, such as large lot zoning, may achieve exclusionary as well as conservation effects in another setting. Compare Steel Hill Dev., Inc. v. Town of Sanbornton, 469 F.2d 956 (1st Cir. 1972) (zoning that achieved conservation effects only, in small coinmunity far from inajor cities, upheld), with Appeal of Kit-Mar Builders, Inc., $439 \mathrm{~Pa}$. 466, $268 \mathrm{~A} .2 \mathrm{~d} 765$ (1970) (zoning that achieved both couservation and exclusionary effects in suburban growth area leld unconstitutional).

11. This famous phrase was first used in Younger v. Harris, 401 U.S. 37, 44 (1971) (Black, J.). See text accompanying notes 238-42 infra.

12. See, eg., Gibbons, Our Federalism, 12 Suffolk U.L. REv. 1087 (1978); Soifer \& Macgill, The Younger Doctrine: Reconstructing Reconstruction, 55 TEx. L. REv. 1141 (1977); Weinberg, The New Judicial Federalism, 29 STAN. L. REv. 1191 (1977).

13. Recognition of the inherent inappropriateness of the exercise of federal jurisdiction in certain classes of cases is not a new phenomenon. For example, even before the Act of August 21, 1937, cl. 726, 50 Stat. 738 (currently 28 U.S.C. $\$ 1341$ (1976)), prohibiting tax suit injunctions, federal courts of equity had reframed from "[i]nterference with state internal econouny and administration [that] . . . necessarily attends injunctions . . . restraining collection of state taxes." 
eral judicial disapproval of such a role should become even more pronounced when the remedies sought would require decrees that interdict ongoing state proceedings or that depart from the private lawsuit model and vindicate group interests by requiring constant federal judicial supervision of compliance by state officials.

Although many federal courts may liave an instinctive aversion to making a federal case out of zoning, they cannot arbitrarily curtail their exercise of jurisdiction. In Cohens v. Virginia ${ }^{14}$ Chief Justice Marshall stated that the Supreme Court had "no more right to decline the exercise of jurisdiction which is given [by the Constitution], than to usurp that which is not given." 15 Eighty-seven years later in Ex parte Young, ${ }^{16}$ Justice Peckham made it clear that this mandate has equal force when applied to lower federal courts, at least where the source of jurisdiction is an act of Congress. Nevertheless, both Congress and the Supreme Court have identified a wide range of situations where the obligation to decide cases gives way to "important countervailing interests." 17 The thesis of this Article is that local land use controversies often present such countervailing imterests and therefore are appropriate cases for the imvocation of the abstention doctrines; some cases actually require such imvocation.

This Article lias a secondary purpose. Examination of recent land use cases where the applicability of the abstention doctrines was at issue slows considerable confusion. While this confusion is both understandable, since the Supreme Court's development of the abstention doctrines has not been altogether clear, ${ }^{18}$ and regrettable, it is perhaps unnecessary. The various forms of abstention are doctrinally distmct, even though they are often confused im application. Thus, by analyzing the recent Supreme Court cases, this Article attempts to delineate the factors critical to mvocation of the different abstention doctrines and to slow how the lower courts should apply them to land use cases.

Accordingly, this Article examines the general operation of the doctrines and their application to land use cases, especially those in which standing considerations do not obviate the necessity for an abstention analysis. Part I discusses the jurisdictional bases of federal land use hitigation, and considers the current status of the traditional

Great Lakes Dredge \& Dock Co. v. Huffman, 319 U.S. 293, 298 (1943). See also Markham v. Allen, 326 U.S. 490, 494 (1946) (denial of federal jurisdiction over probate matters); Popovici v. Agler, 280 U.S. 379, 383 (1930) (denial of federal jurisdiction over doniestic relations controversies).

14. 19 U.S. (6 Wheat.) 264 (1821).

15. Id. at 404 (dictun1).

16. 209 U.S. 123, 143 (1908).

17. Colorado River Water Conserv. Dist. v. United States, 424 U.S. 800,813 (1976).

18. L. Tribe, american Constitutional Law 154 (1978). 
"exhaustion of remedies" requirement. The next three Parts consider, in turn, the classic abstention doctrines: Pullman, Burford, and Younger. Finally, Part V examines the recent Colorado River decision and concludes that it represents a fourth abstention doctrine, closely allied to the Burford and Younger doctrines, yet having a slightly different focus that promises it a life apart.

\section{The Bases of Federal JuRisdiction}

Before 1972, the primary authority that allowed the federal courts to entertain land use challenges was the general federal question jurisdiction conferred by 28 U.S.C. section $1331 .{ }^{19}$ Federal question jurisdiction existed if two requirements were inet: A substantial ${ }^{20}$ federal claim appeared from the facts of a correctly pleaded complaint, ${ }^{21}$ and the claim exceeded the jurisdictional minimum of $\$ 10,000.22$ Typically, the federal claims in land use cases have consisted of constitutional challenges based on the fifth or the fourteenth amendments, although recently they have also been predicated on 28 U.S.C. section $1985,{ }^{23}$ the antitrust laws, ${ }^{24}$ the fair housing laws, ${ }^{25}$ or the existence of an interstate

19. Prior to 1980 the Act read: "The district courts shall have original jurisdiction of all civil actions wherem the matter in controversy exceeds the suin or value of $\$ 10,000$, exclusive of interest and costs, and arises under the Constitution, laws, or treaties of the United States." 28 U.S.C. $\S 1331$ (a) (1976).

20. Bell v. Hood, 327 U.S. 678,682 (1946). The substantiality requirenent is discussed at text accompanying notes $36-78$ infra.

21. The federal claims cannot arise by way of an anticipatory defeuse. See Public Serv. Comın'n v. Wycoff Co., 344 U.S. 237, 248 (1952).

22. The Federal Question Jurisdictional Amendments Act of 1980, Pub. L. No. 96-486, § 2, 49 U.S.L.W. 196 (Jan. 13, 1981), struck the $\$ 10,000$ requirement.

23. 42 U.S.C. $\S 1985(3)$ (1976) provides in relevant part:

If two or more persons . . . conspire . . . for the purpose of depriving, cither directly or imdirectly, any person or class of persous of the equal protection of the Iaws, or of equal privileges and immunities under the laws; . . . the party so injured or deprived may have an action for the recovery of damages occasioned by such injury or deprivation, against any one or inore of the conspirators.

This section requires "soine racial, or perhaps otherwise class-based, invidiously discriminatory animus behind the conspirators' action." Griffin v. Breckenridge, 403 U.S. 88, 102 (1971). Failure to allege that the conspiracy is in sonie way class-based is fatal in zoning cases. See, e.g., Stcphens v. City of Plano, 375 F. Supp. 985, 988 (E.D. Tex. 1974). There is a split in the circuits as to whether a claim is stated under $\$ 1985(3)$ when no state involvement is alleged and the deprivations claimed involve fourteenth amendment rights. Compare Bellamy v. Mason's Storcs, Inc., 508 F.2d 504 (4th Cir. 1974) (state action required), with Action v. Gannon, 450 F.2d 1227 (8th Cir. 1971) (en banc) (state action not required). For a good discussion of $\S 1985$ (3) in a zoning context, see Weiss v. Willow Tree Civic Ass'n, 467 F. Supp. 803 (S.D.N.Y. 1979).

24. See Whitworth v. Perkins, 559 F.2d 378 (5th Cir. 1977), vacated sub nom. City of Inpact v. Whitworth, 435 U.S. 992, judgment reinstated per curiam on remand sub nom. Whitworth v. Perkins, 576 F.2d 696 (Sth Cir. 1978), cert. denied, 440 U.S. 911 (1979).

In City of Lafayette v. Louisiana Power \& Light Co., 435 U.S. 389 (1978), the Court lueld that the state action antitrust immunity doctrine of Parker v. Brown, 317 U.S. 341 (1943), applied to 


\section{compact. $^{26}$}

After 1972 federal courts began to entertain land use claims arising under 42 U.S.C. section $1983^{27}$ and its jurisdictional counterpart, 28

municipalities only in limited circumstances: "[T]he Parker doctrine exempts only anticompetitive conduct engaged in as an act of government by the State as sovereign, or, by its subdivisions, pursuant to state policy to displace competition with regulation or monopoly public service." 435 U.S. at 413. While the fragmentation of the Court in City of Lafayette makes the scope of the holding somewhat nnclear, one commentator suggests that where a inunicipality clains Parker immunity, the judicial inquiry will focus on the nature of the conduct involved. If the anticoinpetitive conduct can be characterized as a sovereign act of government, rather than a proprietary venture, immunity will result. See Comment, The Erosion of State Action Immunity from the Antitrust Laws: City of Lafayette v. Louisiana Power and Light Co., 45 BROOKLYN L. REv. 165, 189 (1978). Under this standard, it is likely that few challenges to land use decisions would be successful, since such decisions are seldoin in furtherance of a inunicipal proprietary activity.

25. 42 U.S.C. $\$ \S 3601-3631$ (1976). The fair housing laws provide a remedy for racial discrimmation, see Evans v. Lynn, 537 F.2d 571, 576-77 (2d Cir. 1975), cert. denied, 429 U.S. 1066 (1977), and sex discrimination, see Braunstein v. Dwelling Managers, Inc., 476 F. Supp. 1323 (S.D.N.Y. 1979), in the rental and sale of housing.

Fair housing lawsuits have certain advantages over suits premised on the equal protection clause, the most important being that they require a showing only of discriminatory effect, not discriminatory purpose. Compare Village of Arlington Heights v. Metropolitan Hous. Dev. Corp., 429 U.S. 252 (1977), (deciding only the equal protection issues), with the court of appeals decision on the Fair Housing Act claim on remand, Metropolitan Hous. Dev. Corp. v. Village of Arlington Heights, 558 F.2d 1283 (7th Cir. 1977), cert. denied, 434 U.S. 1025 (1978). Also, fair housing lawsuits need not overcome the prudential standing rules articulated in Wartl v. Seldin, 422 U.S. 490 (1975). See Gladstone, Realtors v. Village of Bellwood, 441 U.S. 91,114 (1979).

However, there may be disadvantages to the fair housing lawsuit. In Park View Heights Corp. v. City of Black Jack, 454 F. Supp. 1223 (E.D. Mo. 1978), rev'd on other grounds, 605 F.2d 1033 (8th Cir. 1979), cert. denied, 445 U.S. 905 (1980), the court held that "the power of [a] [c]ourt to issue reunedial injunctive relief which interferes with local autonomy in decision-making exists only where a constitutional violation is present." Id. at 1228 (citing Hills v. Gautreaux, 425 U.S. 284,293 (1976)). Simce the prior Black Jack case, United States v. City of Black Jack, 508 F.2d 1179, 1188 (8th Cir. 1974), cert. denied, 422 U.S. 1042 (1975), had not determined the existence of a constitutional violation, but only a violation of the fair housing laws, the court refused to cxpand the prior order of the trial court and require city officials to take whatever action was necessary to effectuate the desired housing. A similar restriction, arising out of inherent federalism limitations on the granting of equitable relief, is suggested in Metropolitan Housing Dev. Corp. There the court distinguished between requiring affirmative action on the part of the defendant and an injunction preventing the defendant froin interfering with plaintiff's atteinpt to build integrated housing, the former being objectionable as a "massive judicial intrusion on private autonouny." 558 F.2d at 1293. Still another problem with fair housing lawsuits from a plaintiffs perspective is that they inay require exhaustion of administrative remedies. See 42 U.S.C. $\$ 3610$ (1977).

26. In League to Save Lake Tahoe v. B.J.K. Corp., the test for determining whether construction of the Regional Planning Agency's land use ordinance presented a federal question was a pragmatic one: "Whether interstate conflicts in the interpretation and application of the Ordinance may . . substantially affect the effective functioning of the Coinpact and whether, absent a federal trial forum, existing judicial mechanisms supply a practical ineans for resolving such conflicts." 547 F.2d 1072, 1074 (9th Cir. 1976); accord, California Tahoe Regional Planning Agency v. Jennings, 594 F.2d 181 (9th Cir.), cert. denied, 444 U.S. 864 (1979). The action of regional planning agency officials acting pursuant to an interstate compact nay also be "under color of state law" for purposes of 42 U.S.C. $\$ 1983$ and 28 U.S.C. $\S 1343(3)$. See Lake Country Estates, Inc. v. Tahoe Regional Planning Agency, 440 U.S. 391, 399-400 (1979).

27. 42 U.S.C. $\& 1983$ (1976) provides as follows:

Every person who, under color of any statute, ordinance, regulation, custoin, or usage, 
U.S.C. section 1343(3). ${ }^{28}$ It was unclear for many years whether section 1983 applied to "property" claims, largely because of Justice Stone's concurring opinion im Hague v. $\mathrm{ClO}^{29}$ Justice Stone had concluded that section 1983 applied only to "the cause of action [the gist of which] was not damage or injury to property, but unconstitutional infringement of a right of personal liberty not susceptible of valuation in money." ${ }^{30}$ The doubts on this issue were settled in Lynch v. Household Finance Corp. ${ }^{31}$ which rejected Justice Stone's distinction. Lynch's enlargement of section 1983's scope made it easier and more attractive ${ }^{32}$ for plaintiffs to bring land use cases in the federal courts, since actions premised on section 1343(3), unlike those premised on section 1331, were freed from the jurisdictional amount requirement, the restraints of the Anti-Injunction Act, ${ }^{33}$ and the traditional requirement that plaintiff first exhaust possible administrative remedies. ${ }^{34}$

Nevertheless, there are two threshold requirements that plaintiffs must meet before any federal jurisdiction can exist. First, the federal claim must be substantial. Second, there is a less settled requirement, despite the apparent rule of nonexhaustion followed in some federal

of any State or Territory, subjects, or causes to be subjected, any citizen of the United States or other person within the jurisdiction thereof to the deprivation of any rights, privileges, or immunities secured by the Constitution and laws, shall be liable to the party injured in an action at law, suit in equity, or other proper proceeding for redress. 28. 28 U.S.C. $\$ 1343$ (1976) provides as follows:

The district courts shall have original jurisdiction of any civil action authorized by law to be commenced by any person:

(3) To redress the deprivation, under color of any State law, statute, ordinance, regulation, custom or usage, of any right, privilege of imniunity secured by the Constitution of the United States or by any Act of Congress providing for equal rights of citizens or of all persons within the jurisdiction of the United States . . . .

Although 28 U.S.C. $\S 1343(3)$ is frequently referred to as the "jurisdictional counterpart" of $\S 1983$, see, e.g., Lynch v. Household Fin. Corp., 405 U.S. 538, 540 (1972), not all $\S 1983$ claims can be jurisdictionally premised on $\S 1343$. In Maine v. Thiboutot, $100 \mathrm{~S}$. Ct. 2502 (1980), the Court held that $\S 1983$ encompasses claims based on purely statutory federal law, such as the Social Security Act. However, the jurisdictional statute is narrower; it specifically linnits district court jurisdiction to cases where the plaintiff alleges a violation of the. Constitution or of a statute "providing for equal rights" or "civil rights." Therefore, many purely statutory $\S 1983$ cases must presumably be brought under 28 U.S.C. $\S 1331$ or $\S 1337$. See Maher v. Gagne, 100 S. Ct. 2570, $2574 \mathrm{n} .11$ (1980). For a nonexhaustive catalog of federal statutes that might give rise to $\$ 1983$ actions, many of whieh relate to land use, see Maine v. Thiboutot, $100 \mathrm{~S}$. Ct. at 2519-21.

29. 307 U.S. 496 (1939).

30. Id. at 531 (Stone, J., concurring).

31. 405 U.S. 538,542 (1972).

32. Another advantage of proceeding under $\S 1983$ is that under the Civil Rights Attorneys' Fees Award Act of 1976, 42 U.S.C. $\$ 1988$, a plaintiff prevailing on the merits may recover attorneys' fees as part of the award of costs. See, e.g., Hutto v. Finney, 437 U.S. 678 (1978).

33. 28 U.S.C. $\$ 2283$ (1976). It prohibits the use of federal injunctive power to "stay proceedings in a State court." For further discussion of the Act, see text accoinpanying notes 232-37 infra.

34. See text accompanying notes 79-99 infra. 
claims, that the plaintiff exhaust state administrative, and possibly state judicial remedies before federal jurisdiction will be found to exist.

\section{A. The Requirement That the Federal Question Be Substantial}

A federal question is too insubstantial to support federal jurisdiction if it is "obviously without merit, or 'because its unsoundness so clearly results froin the previous decisions of [the Supreme Court] as to foreclose the subject and leave no rooin for the inference that the questions sought to be raised can be the subject of controversy." "35 The sigmificance of the substantial federal question requirement is two-fold. First, if it is not met, there is no federal jurisdiction. ${ }^{36}$ Second, if it is inet, the plaintiff may litigate any state law claims properly pendent to the federal claims: If " $[t]$ he state and federal claims . . . derive from a common nucleus of operative fact . . . [and the] plaintiff . . . would ordmarily be expected to try them all im one judicial proceedimg, [and the federal issues are substantial], there is power in federal courts to hear the whole." 37 The exercise of this power, termed pendent jurisdiction, is im the district court's discretion. ${ }^{38}$ Although the question of power should be decided on the pleadings, the court should keep open throughout the litigation the question of whether its assumption of pendent jurisdiction was proper. The state claims should be dismissed if they are found to constitute the real body of the case. ${ }^{39}$ Thus, there may be cases that present federal questions substantial enough to sustain federal jurisdiction, but not substantial enough to justify the exercise of pendent jurisdiction.

The land use plaintiff who wishes to utilize the federal forum may have difficulty in meeting the substantial federal question test ${ }^{40}$ or $\mathrm{m}$ persuading the court to exercise pendent jurisdiction even when there is

35. Levering \& Garrigues Co. v. Morrin, 289 U.S. 103, 105-06 (1933) (quoting numerous cases).

36. Bell v. Hood, 327 U.S. $678,682-83$ (1946).

37. United Mine Workers v. Gibbs, 383 U.S. 715, 725 (1966) (einphasis in original) (rejecting the more himited standard of Hurn v. Oursler, 289 U.S. 238 (1933)).

38. United Mine Workers v. Gibbs, 383 U.S. at 726. The factors that should guide the court's discretion include whether the state issues predominate, and the likeliliood of jury confusion caused by a multiplicity of issues and divergent theories of relief. Id. at 726-27.

39. Id. at 727; see, e.g., United States v. Town of North Henpstead, 610 F.2d 1025 (2d Cir. 1979) (propriety of exercise of pendent jurisdiction raised for first time by the appellate court).

40. Defendant should answer plaintiff's complaint by asserting the court's lack of subject matter jurisdiction in that the controversy fails to present a substantial federal question. See FED. R. Civ. P. 12(b)(1). Such a determimation would inean that the district court has no discretion to exercise pendent jurisdiction. Even if the parties do not raise the defense of lack of subject matter jurisdiction, the court may, on its own inotion, raise it at any time. FED. R. CIv. P. 12(h)(3); see, e.g., Blaekman v. City of Big Sandy, 377 F. Supp. 771, 773 (E.D. Tex. 1974) (dismissal after trial), aff'd, 507 F.2d 935 (Sth Cir. 1975). 
a substantial federal question. ${ }^{41}$ A brief exammation of substantive land use law suggests that the substantiality requirement should pose a significant obstacle to federal jurisdiction im many land use cases.

A complamt that claims a violation of the due process or equal protection clauses of the fourteenth amendment does not state a cause of action if it alleges merely that state officials departed from statutory procedures yet produced results that would be constitutional had the same actions conformed to the required procedure. The classic example occurred in Snowden v. Hughes. ${ }^{42}$ An Illinois citizen brought an action for damages in federal court against the individual members of the state primary canvassing board, claiming that the board had improperly refused to certify the results of a primary that had elected him a representative to the state assembly. The Supreme Court held that plaimtiff asserted no right protected by the fourteenth ainendment. Thus, he failed to state a cause of action:

But not every denial of a right conferred by state law involves a denial of the equal protection of the laws .... [W] [Were the official action purports to be in conformity to the statutory classification, an erroneous or mistaken performance of the statutory duty, although a violation of the statute, is not without inore a denial of the equal protection of the laws.

[Such administration of the law] is not a denial of equal protection unless there is shown to be present in it an element of intentional or purposeful discrimination. ... .

If the action of the Board is official action it is subject to constitutional infirmity to the same but no greater extent than if the action were taken by the state legislature. Its illegality under the statc statute can neither add to nor subtract from its constitutional validity. . . . And state action, even though illegal undcr state law, can be no more and no less constitutional under the Fourteenth Amendment than if it were sanctioned by the state legislature. ${ }^{43}$

Fourteenth amendment land use challenges should not sustain federal jurisdiction if they merely allege that a state officer ${ }^{44}$ or other

41. See, e.g., Rogin v. Bensalem Township, 616 F.2d 680, 697 (3d Cir. 1980); Sambo's Restaurants, Inc. v. City of Ann Arbor, 473 F. Supp. 41, 48 (E.D. Mich. 1979); Art Neon Co. v. City and County of Denver, 357 F. Supp. 466, 467 (D. Colo.), rev'd on other grounds, 488 F.2d 118 (10th Cir. 1973), cert. denied, 417 U.S. 932 (1974); Nationwide Amusements, Inc. v. Nattim, 325 F. Supp. 95, 98 (W.D. La.), rev'd on other grounds, 452 F.2d 651 (4th Cir. 1971).

42. 321 U.S. 1 (1944).

43. Id. at 8, 11; accord, City of Boston v. Massachusetts Port Auth., 444 F.2d 167, 168-69 (1st Cir. 1971).

44. In most land use cases, the eleventh amendment poses no barrier to suit because its immumity does not extend to counties and municipal corporations. Mt. Healthy City School Bd. of Educ. v. Doyle, 929 U.S. 274, 279-81 (1977). In addition, after Ex parte Young, 209 U.S. 123 (1908), the eleventh amendment does not offer siguificant protection to state officials. Neverthe- 
official acting under color of state law has incorrectly or arbitrarily applied an otherwise constitutional state law that affects no federally protected right. This rule should limit the number of land use cases that can reach trial in federal court. Harrison v. Brooks ${ }^{45}$ illustrates this point. Plaintiffs hived in a residentially zoned area. A factory was built near plaintiffs' hoine. Two driveways to the factory were constructed across the residentially zoned area, on both sides of plaintiffs' home, and were used daily by several hundred people and trucks. Various town officials did nothing about enforcing the zoning ordinance until plaintiffs won a suit against them in state court. The federal court of appeals approved the district court's dismissal of plaintiffs' eight section 1983 causes of action on the ground that "[t] between alleging an act to be inerely 'wrongful' or 'unlawful' and the " "showing of purposeful discrimination"... necessary in order to raise a claim under the Fourteenth Amendment., "46

Zoning actions by local officials that fail to follow statutory procedures may be invalid as a inatter of state law, but raise no federal constitutional concerns. However, official action pursuant to state procedures that violates the more fundamental principles of fairness required by fourteenth ainendment procedural due process does raise a federal constitutional claim, ${ }^{47}$ although federal constitutional procedural protection in the zoning context may be further attenuated by the characterization of the decisioninaking process. Where the nature of the process is viewed as quasi-legislative, procedural fairness-notice, fact finding, etc.-is not required unless the process is arbitrary and capricious. ${ }^{48}$ Only where the decision occurs in a quasi-adjudicative setting do further procedural minima become necessary. ${ }^{49}$

less, eleventh amendment defenses continue to be interposed in land use cases, usually without success. See, e.g., Lake Country Estates, Inc. v. Tahoe Regional Planning Agency, 440 U.S. 391 (1979).

45. 446 F.2d 404 (1st Cir. 1971).

46. Id. at 407 (quoting City of Boston v. Massachusetts Port Auth., 444 F.2d 167, 169 (1st Cir. 1971)).

47. To state a federal constitutional claim, plaintiff must allege that the ultra vires conduct infringes a right guaranteed by the federal Constitution. See Crocker v. Hakes, 616 F.2d 237, 241 (5th Cir. 1980); Sixth Camden Corp. v. Township of Eveshain, 420 F. Supp. 709, 725-27 (D.N.J. 1976). Note also that separation of state governmental powers arguments made in the land use context usually are not of federal constitutional dimension. See, e.g., Ellentuek v. Klein, 570 F.2d 414, 428 (2d Cir. 1978).

48. South Gwinnett Venture v. Pruitt, 491 F.2d 5, 7 (5th Cir.) (en banc), cert. denied, 419 U.S. 837 (1974); Stephens v. City of Plano, 375 F. Supp. 985,987 (E.D. Tex. 1974). Contra, Sixth Camden Corp. v. Township of Evesham, 420 F. Supp. 709, 726-27 (D.N.J. 1976).

49. Perhaps the distinction between quasi-legislative and quasi-adjudicative decisions does not have inuch merit, and zoning in general, not just the preparation of comprehensive land use plans, should be characterized as a legislative function. South Gwinnett Venture v. Pruitt, 482 F.2d 389, 393-94 (5th Cir. 1973) (Bootle, J., dissenting), rev'd en banc, 491 F.2d 5 (5th Cir.), cert. denied, 419 U.S. 837 (1974). 
The evolving federal substantive law applicable to constitutional zoning challenges increases the likelihood that many such challenges will prove too frail to support other state claims under pendent jurisdiction. The principle of the landmark case of Village of Euclid v. Ambler Realty $\mathrm{Co}^{50}$ that a zoning regulation is constitutionally permissible if reasonably related to "public lealth, safety, morals, or general welfare" ${ }^{11}$ has lost whatever restrictive force it had at the time of its introduction in the era of substantive due process. Berman v. Parker ${ }^{52}$ and Village of Belle Terre v. Boraas ${ }^{53}$ lave narrowed the dimensions of constitutional uncertainty in zoning cases; zoning regulations are now presumptively valid and inust meet only a rational basis test ${ }^{54}$ unless shown to be based discriminatorily upon race. ${ }^{55}$ The consequence is that once-legitimate constitutional challenges are now frivolous and hence should increasingly be found unsupportive of pendent jurisdiction.

Attempts to invoke the protections of the Bill of Rights through the fourteenth amendment in the zoning context and thereby shift the burden of proof to the defendants to identify a compelling state interest $^{56}$ for the land use regulations liave been largely unsuccessful. Thus, in Village of Belle Terre v. Boraas ${ }^{57}$ the Supreme Court held that no fundamental right was infringed by a zoning restriction that limited a residential area to single-family use. ${ }^{58}$ Only Justice Marsliall thought that the restrictions burdened the plaintiff' first amendment right of freedom of association. ${ }^{59}$

Fifth amendment taking claims under the fourteenth amendment have not met with any greater success than the first ainendment attempts. The courts have repeatedly lield that mere diminution in value caused by a zoning decision is not a fifth amendment taking. ${ }^{60}$ So typi-

50. 272 U.S. 365 (1926).

51. Id. at 395 .

52. 348 U.S. 26, 32 (1954).

53. 416 U.S. 1, 8 (1974).

54. See, e.g., Stone v. City of Maitland, 446 F.2d 83, 87 (5th Cir. 1971).

55. Village of Arlington Heights v. Metropolitan Hous. Dev. Corp., 429 U.S. 252 (1977). Whether classifications based on wealth trigger heightened scrutiny is still an open question. See Dehight, Inc. v. Baltimore County, 475 F. Supp. 754, 761 (D. Md. 1979) (dictum).

56. Statimg such a cause of action is extremely desirable for plaintiffs, since it is unlikely that land use officials will be able to justify their decisions by any compelling state interest. See Gunther, The Supreme Court, 1971 Term-Foreword: In Search of Evolving Doctrine on a Changing Court: A Model for a Newer Equal Protection, 86 HARv. L. REv. 1, 8 (1972) (scrutiny is " 'strict' in theory, fatal in fact").

57. 416 U.S. 1 (1974).

58. Id. at 7. But see Moore v. City of E. Cleveland, 431 U.S. 494 (1977) (plurality opinion) (invalidating a similar ordinance).

59. 416 U.S. at 15-20 (Marshall, J., dissenting).

60. See Penn Cent. Transp. Co. v. New York City, 438 U.S. 104 (1978); Hadacheck v. Sebastian, 239 U.S. 394 (1915) (diminution of 92\%); Rogin v. Bensalem Township, 616 F.2d 680, 692 
cal is this result that it would seem that such complaints, absent some highly atypical allegations of total confiscation of value, would inevitably succumb to a inotion to dismiss for failure to allege a substantial federal question, ${ }^{61}$ or at least to a dismissal of the pendent state claims under the discretionary principles of pendent jurisdiction. ${ }^{62}$

Several recent lower federal court decisions, however, suggest a possible avenue for successful fifth amendment taking litigation. In Gordon v. City of Warren, ${ }^{63}$ Barbaccia v. County of Santa Clara, ${ }^{64}$ and Sixth Camden Corp. v. Township of Evesham, ${ }^{65}$ the courts lield that particular land use regulations that were mvalid as applied could be takmgs without just compensation. The theory underlying these decisions seemed to be that a restramt on the use of land during the period required to mount a successful state court challenge ${ }^{66}$ or to obtain rezoning ${ }^{67}$ may itself constitute a taking for purposes of the fiftl amendment.

Serious conceptual and policy problems inhere in the results of these cases, however. Only where a restrictive regulation is upleeld is the land robbed of all value. In cases where a state court grants a declaration of invalidity, or the land is rezoned, the diminution im value is only partial; total use value is "taken" for a limited period only. To treat the limited temporal restramt as a taking of a separate and distmct bundle of property rights comparable to, for imstance, the taking of a leasehold is to commit the conceptual blunder condemned by Justice Brandeis in Pennsylvania Coal Co. v. Mahon:"68 "The rights of an owner, as against the public, are not mcreased by dividing the interests in his property imto surface and subsoil. The sum of the rights in the parts cannot be greater than the riglits in the whole."69 An action that reduces the value of only a portion of a property is not a taking of the

n.57 (3d Cir. 1980); William C. Haas \& Co. v. City \& County of San Francisco, 605 F.2d 1117, 1120 (9th Cir. 1979) (diminution of 95\%), cert. denied, 445 U.S. 928 (1980); Steel Hill Dev., Inc. v. Town of Sanbornton, 469 F.2d 956, 963 (1st Cir. 1972); Wigginess, Inc. v. Fruchtman, 482 F. Supp. 681, 685 n.5 (S.D.N.Y. 1979), cert. denied, 49 U.S.L.W. 3235 (U.S. Oct. 7, 1980); Shrader v. Horton, 471 F. Supp. 1236, 1242-43 (W.D. Va. 1979); Kent Island Joint Venture v. Smith, 452 F. Supp. 455, 460-61 (D. Md. 1978).

61. Cf. M.J. Brock \& Sons v. City of Davis, 401 F. Supp. 354, 359 (N.D. Cal. 1975) (court refused motion to dismiss because complaint alleged that zoning regulation rendered site "snbstantially valueless," but warned that plaintiff was unlikely to prevail on the taking issue on motion for summary judgment).

62. See, e.g., Wigginess, Inc. v. Fruchtman, 482 F. Supp. 681,693 (S.D.N.Y. 1979), cert. denied, 49 U.S.L.W. 3235 (U.S. Oct. 7, 1980).

63. 579 F.2d 386 (6th Cir. 1978).

64. 451 F. Supp. 260 (N.D. Cal. 1978).

65. 420 F. Snpp. 709 (D.N.J. 1976).

66. Gordon v. City of Warren, 579 F.2d at 387; Sixth Camden Corp. v. Township of Eveshain, 420 F. Supp. at 721-22.

67. Barbaccia v. County of Santa Clara, 451 F. Supp. at 265-66.

68. 260 U.S. 393 (1922).

69. Id. at 419 (Brandeis, J., dissenting). 
whole; such an action cannot be characterized as a taking by only looking at its inpact on the part of the property it affects.

Moreover, the results in these teinporary taking cases do not seem consistent with the principles of res judicata, which should require that the plaintiff seek compensation for the taking in the original suit to invalidate the ordinance. Failure to do so should result in the damage claim for the teinporary taking being merged into the original judginent, thus foreclosing a further suit in federal court. ${ }^{70}$

The entire doctrine of implied taking is conceptually suspect as an appropriate tool for dealing with the consequences of police power regulations ${ }^{71}$ and particularly suspect from a policy standpoint as a method to coinpensate for the delays inherent in normal governmental administration. Nor is it consistent with the cases holding that misuse of legal procedure, without more, does not rise to the level of a constitutional wrong protected by section $1983 .{ }^{72}$ Because the consequence of accepting the temporary takings doctrine is that potentially every successful variance case could give rise to government liability, it should not be expanded into fifth amendment law.

However, the recent case law does provide certain advantages for prospective federal plaintiffs. They are more likely to be able to state a substantial federal claim now that municipalities are "persons" within the meaning of section $1983,{ }^{73}$ although it is possible that municipalities and local boards will retain some measure of immunity that will limit the exercise of pendent jurisdiction over related state claims against them. Monell v. Department of Social Services ${ }^{74}$ held that section 1983 liability cannot attach to inunicipalities solely on a respondeat superior theory; the inunicipal officers nuust be carrying out official policy if liability is to attach. ${ }^{75}$ Lower federal courts also have consistently held that local legislators are absolutely immune from federal scrutiny into their legislative motivation in land use controversies and froin personal econonnic liability predicated upon their legislative acts. $^{76}$ However, Owen v. City of Independence ${ }^{77}$ precludes municipali-

70. See F. James \& G. Hazard, Civil Procedure § 11.2, at 531-32 (2d ed. 1977).

71. See notes $146-47$ infra.

72. See, e.g., Beker Phosphate Corp. v. Muirhead, 581 F.2d 1187, 1189 (5th Cir. 1978) (per curiam).

73. Monell v. Department of Social Servs., 436 U.S. 658 (1978) (overruling Monroe v. Pape, 365 U.S. 167 (1961) and City of Kenosha v. Bruno, 412 U.S. 507 (1973)).

74. 436 U.S. 658 (1978).

75. Id. at 691 .

76. See, e.g., Gorman Towers, Inc. v. Bogoslavsky, 626 F.2d 607, 611-14 (8th Cir. 1980) (citing cases). But see Nelson v. Knox, 256 F.2d 312, 314-15 (6th Cir. 1958) (dictum).

The problem of defining a legislative act may be troublesome when the same local governmental official acts im a legislative capacity and in an administrative or quasi-judicial capacity. See, e.g., Rockbridge Assocs. Ltd. v. Pruitt, 341 F. Supp. 703, 706 (N.D. Ga. 1971) (decision by 
ties from raising the shield of good faith immunity that protects local officials from personal liability. In the land use context, Owen creates the functional equivalent of vicarious liability for municipahties, since almost invariably such cases involve inunicipal officials carrying out official policy.

Owen may heighten interest in the federal forum for land use litigation, considering that most states provide a far broader umbrella of mumicipal immunity for state law torts than the Supreme Court has now defined for constitutional torts. ${ }^{78}$ Moreover, Owen may permit a greater exercise of pendent jurisdiction in a broader range of circumstances than previously, since federal courts are no longer permitted to dismiss pendent state law claims summarily on the ground that the inunicipahty is clearly immune from a section 1983 suit because of sovereign immunity principles.

\section{B. Exhaustion of State Remedies}

\section{Administrative Exhaustion}

The rule that a litigant normally must exhaust administrative remedies before challenging state action in a federal court was well established by the time land use hitigation began to appear in federal court. ${ }^{79}$ Thus, a plamtiff had to exhaust a state administrative remedy unless it was madequate to vindicate plaintiff's federal claim. ${ }^{80}$ The justification for the rule was that it facilitated the efficient allocation of judicial resources by allowing state agencies an opportunity to correct their own errors, thus reducing the likelihood of resort to federal court yet preserving the hitigant's ultimate choice of forum. The federal court received the benefit of the administrative agency's expertise, but since res judicata and collateral estoppel primciples did not apply, it was not

county commissioners on rezoning petition quasi-legislative, thus legitimizing their use of nonrecord materials), aff'd en banc, 491 F.2d 5 (5th Cir.), cert. denied, 419 U.S. 837 (1974).

77. 445 U.S. $622,638-50$ (1980).

78. Id. at 680-83 (Powell, J., dissenting).

79. See C. WRIGHT, LAw OF FeDERAL CourTs § 49, at 210 (3d ed. 1976) (citing cases).

80. Some courts have held that Village of Euchd v. Ambler Realty Co., 272 U.S. 365 (1926), is authority for the proposition that zoning challenges premised on $\$ 1331$ jurisdiction are excepted from any rule of administrative exhaustion. See, e.g., Lerner v. Town of Islip, $272 \mathrm{~F}$. Supp. 664, 668 (E.D.N.Y. 1967). However, unlike the unique facial challenge in Euclid, the typical federal zoning controversy presents an as-applied challenge. Moreover, the Euclid Court's discussion of the plaintiff's failure to utilize available administrative procedures related not to an exhaustion requirement per se, but to traditional equity requirements for imjunctive relief. Compare Euclid with Nectow v. City of Caunbridge, 277 U.S. 183 (1928), a typical as-applied challenge where it is difficult to characterize diminished economic value as irreparable, since the unused variance granting procedure seems uniquely designed to aneliorate injury, and nay clearly be an adequate remedy at law. Note, however, that in Nectow potential administrative variance remedies had been exhausted. 
bound by the agency's determinations. ${ }^{81}$

The primary exception to the administrative exhaustion requirement occurs in cases in which the plaintiff seeks to vindicate constitutional claims under section 1983. The precursor of change on the question of whether section 1983 requires admimistrative exhaustion began with the 1961 holding in Monroe v. Pape ${ }^{82}$ that section 1983 actions did not require exhaustion of state judicial remedies. Two years later the Supreme Court in McNeese v. Board of Education ${ }^{83}$ extended the Monroe principle and held that the plaintiff in a section 1983 action need not pursue an administrative remedy that offered only "tenuous protection." 84 The implications of McNeese did not appear significant for inost land use challenges until Lynch v. Household Finance Corp. ${ }^{85}$ brought sucl cases within section 1983's anbit in 1972. Since land use litigation is particularly susceptible to statutory imperatives regarding the use of the administrative process ${ }^{86}$ the combination of McNeese and Lynch makes it easier to bring section 1983 land use hitigation in federal court.

The section 1983 exception of McNeese probably would not apply to all zoning cases that could be cast in section 1983 terms, however. The scope of the section 1983 "no admimstrative exhaustion" rule is lessened somewhat by the McNeese inajority's persistent emphasis on the inadequacy of the administrative remedy at issue. ${ }^{87}$ The contimued expressions of doubts as to the wisdonn and the necessity of an inflexible and umiversal exception to the general rule also threaten its continued viability. ${ }^{88}$

In McNeese Justice Douglas stated that one purpose of section 1983 was "to provide a remedy in the federal courts supplementary to any remedy any State might liave." 89 But such an open-ended supplementary remedy might entail practical problems. The two inost serious

81. See Comment, Exhaustion of State Administrative Remedies in Section 1983 Cases, $41 \mathrm{U}$. CH1. L. REV. 537, 540-42 (1974).

82. 365 U.S. 167,183 (1961).

83. 373 U.S. 668 (1963).

84. Id. at 676 .

85. 405 U.S. 538 (1972). See text accompanymg notes 29-34 supra.

86. Virtually all zoning enabling acts provide for a variance procedure whereby a landowner may seek a tailored exception from the application of generally valid use or dimensional regulations in hardship situations. See generally 3 R. ANDERSON, AMERICAN LAW OF ZONING \& 18.01 (2d ed. 1977).

87. 373 U.S. at 674-76; see 17 C. Wright, A. Miller \& E. Cooper, Federal Practice AND Procedure § 4233, at 375 (1978).

88. See, e.g., Comment, supra note 81 , at 592-56.

89. 373 U.S. at 672 . In Monroe v. Pape, 365 U.S. 167 (1961), Justice Douglas articulated three other aims of $\S 1983$ : (1) to override certain kinds of state laws; (2) to provide "a remedy where the state law was inadequate;" and (3) "to provide a federal remedy where the state remedy, although adequate in theory, was not available in practice." Id. at 173-74. 
of these are the burden on federal dockets and the extension of federal jurisdiction to cases previously left to the states that involve federal issues of minor importance but that simultaneously involve important state interests. ${ }^{90}$

The difficulties of using section 1983 as a supplementary remedy have led a majority of the Justices to adopt the view that the key as to whether state administrative reinedies must be exhausted is the adequacy of such remedies. ${ }^{91}$ Cases invoking the administrative exhaustion exception are exemplified by Gibson v. Berryhill..$^{92}$ The Alabama Board of Optometry, whose inembership was limited to those optometrists who were members of the Alabama Optometric Association, whose membership in turn was limited to those optometrists not einployed by others, was empowered to decide whether to delicense plamtiffs for unprofessional conduct-i.e., their employinent by others. Plamtiffs sought an mjunction against the pending delicensing proceedmgs. The Court held that they need not exhaust administrative remedies:

Whether this is invariably the case even where, as here, a license revocation proceeding has been brought by the State and is pending before one of its own agencies and where the individual charged is to be deprived of nothing until the completion of that proceeding, is a question we need not now decide; for the clear purport of appellees' complaint was that the State Board of Optometry was unconstitutionally constituted and so did not provide thein with an adequate administrative remedy requiring exhaustion. Thus, the question of the adequacy of the administrative remedy, an issue which under federal law the District Court was required to decide, was for all practical purposes identical with the inerits of appellees' lawsuit. ${ }^{93}$

Similar sentiments have been expressed in other cases, ${ }^{94}$ suggestimg that the adequacy of the state proceedings is the key issue.

The strongest attack on a broad readimg of the section 1983 administrative exhaustion exception appears in the dissenting opimions of Chief Justice Burger and Justice Stewart in Moore v. City of East Cleve-

90. See Note, Limiting the Section 1983 Action in the Wake of Monroe v. Pape, 82 Harv. L. REV. 1486, 1487 (1969). Some lower federal courts have expressed similar doubts. See, e.g., Eiseu v. Eastman, 421 F.2d 560, 569 (2d Cir. 1969) (limiting McNeese to administrative remedies which are inadequate or futile), cert denied, 400 U.S. 841 (1970).

91. But see Gibsou v. Berryhill, 411 U.S. 564, 581 (1973) (Brennan and Marshall, JJ., concurring) (it is clear that $\S 1983$ has no administrative exhaustion requirement).

92. 411 U.S. 564 (1973).

93. Id. at 574-75.

94. See, e.g., Barry v. Barchi, 443 U.S. 55, 63 n.10 (1979) (White, J.) (Gibson cited narrowly); Ohio Bureau of Employmeut Servs. v. Hodory, 431 U.S. 471, $478 \mathrm{n} .8$ (1976) (limiting Gibson to its facts); Rnnyon v. McCrary, 427 U.S. 160, 186 n.* (1976) (Powell, J., concurring) (criticizing expansive reading of $\S 1983$ exhaustion exception). 
land. ${ }^{95}$ There a zoning ordinance defined "family" in such a way as to make it a crime for plaintiff and her two grandsons, who were cousins rather than brothers, to he in the same single-family home. Plaintiff did not request that the Board of Building Code Appeals grant her a variance froun the ordinance's command, although the Code gave the Board such power. The Chief Justice expressed unequivocably his belief that exhaustion of state or local administrative remedies should be a prerequisite to relief in any federal forum. ${ }^{96}$ Sinilarly, Justice Stewart's dissent, although purporting to eschew any general requirement of administrative exhaustion, nevertheless would seen to require it in zoning challenges preinised on the equal protection clause. ${ }^{97}$ The force of these dissenting opinions and the court's consideration of the interplay between the exhaustion requirement and the abstention doctrines ${ }^{98}$ suggest that failure to exhaust state administrative remedies in the property context may be fatal to federal jurisdiction. ${ }^{99}$

\section{Judicial Exhaustion}

The general rule is that a plaintiff need not exhaust state judicial remedies in order to invoke federal jurisdiction over a clainied constitutional infringement. ${ }^{100}$ State judicial exhaustion is not required because to do so would generally foreclose federal court proceedings on the clainis because of the principles of res judicata.

One apparent exception to the general rule occurs in taking cases that involve direct interference with certain traditionally recognized and protected "sticks" out of the property "bundle"-e.g., dramage, access, and other corporeal and incorporeal hereditaments. ${ }^{101}$ Some lower federal courts have held that the existence of an unresorted-to state compensation remedy that includes judicial review means that no

95. 431 U.S. 494, 521 (1977) (Burger, C.J., dissenting); id. at 531 (Stewart and Rehnquist, JJ., dissenting).

96. Id. at 523-24 (Burger, C.J., dissenting).

97. Id. at 541 (Stewart, J., dissenting).

98. See text accoinpanying notes $285-91$ infra.

99. Cf. Ingraham v. Wright, 430 U.S. 651,701 (1977) (Stevens, J., dissenting) (in the property context, a postdeprivation state remedy may be all the fourteenth ainendinent requires).

100. Monroe v. Pape, 365 U.S. 167 (1961) (no requirement for $\$ 1983$ actions); Alabama Pub. Serv. Comm'n v. Southern Ry. Co., 341 U.S. 341, 359 (1951) (Frankfurther, J., concurring); Home Tel. \& Tel. Co. v. Los Angeles, 227 U.S. 278 (1913). A longstanding exception to this principle applies where federal equity power is invoked to restrain state officers from the collection of allegedly unconstitutional state taxes. Mathews v. Rodgers, 284 U.S. 521 (1931); accord, Great Lakes Dredge \& Dock Co. v. Huffman, 319 U.S. 291 (1943) (extending Mathess principle to suits for declaratory relief); 28 U.S.C. $\$ 1341$ (1976).

101. For recent cases applying the "property stick" concept to fifth amendment claims, see Pruneyard Slropping Center v. Robins, 100 S. Cl. 2035, 2041 (1980); Kaiser Aetna v. United States, 444 U.S. 164, 176 (1979). 
constitutional deprivation can be claimed. ${ }^{102}$ The rationale of such decisions is based on the statement that "the relevant constitutional command, after all, is that a state must 'pay a just compensation for property taken for public use." "103 It is unclear whether this statement imports an exception to the general rule against requiring exhaustion of state judicial remedies, or whether it is predicated on an assumption that a fourteenth amendment deprivation accrues only when the state has had an opportunity to refuse compensation by denying any state remedy at all. Either theory would require some tinkering with established doctrine. ${ }^{104}$

There is a tension between the general proposition that state judicial remedies need not be exhausted and the principles underlying the various abstention doctrines. Three Justices recently indicated their disenchantment with the view that there is no necessity for exhaustion of state judicial remedies in section 1983 actions. ${ }^{105}$ They argued that

102. O'Grady v. City of Montpelier, 573 F.2d 747, 752 (2d Cir. 1978); Light v. Blackwell, 472 F. Supp. 333 (E.D. Ark. 1979); Kao v. Red Lion Mun. Auth., 381 F. Supp. 1163 (M.D. Pa. 1974). But see Jim Young Dev. Corp. v. State Highway Comm'n, 56 F.R.D. 38, 42 (W.D. Mo. 1971).

103. O'Grady v. City of Montpelier, 573 F.2d 747, 752 (2d Cir. 1978).

104. It could be argued that the application of state judicial exhaustion requirements to taking cases is analogous to the doctrine of Prentis v. Atlantic Coastline Co., 211 U.S. 210 (1908), that federal courts must postpone review of rate setting orders until statutory appeals to the state courts are completed, if the state review is tantamount to culmination of the legislative process. Thus, if a taking case proceeds on a theory of mverse condemnation and the plaintiff seeks only monetary compensation, see, e.g., Agins v. City of Tiburon, 100 S. Ct. 2138 (1980), it could be argued that the case involves an exercise of the legislative power of eminent domain that is unripe for challenge in a federal forum until a state court has reviewed the action and decided the amount of compensation due under state law. The difficulty with such an argument is that in most cases the plaintiff requests not only damages but alternatively injunctive or declaratory relief, and the real issue is the legality and constitutionality of the purported exercise of the police power.

Even if compensatory inverse condemnation cases were excepted from the "no exhaustion of state judicial remedies" rule, it would presumably remain intact for other types of constitutional challenges. See generally 17 C. WRIGHT, A. MILLER \& E. CoOPER, supra note 87, at \& 4233. Thus, the rule would be applicable if the challenge were cast in terms of substantive due process rather than inverse condemnation. For example, where the gist of the landowner's case is that the application of a zoning ordinance to a particular tract is unreasonable, the plaintiff will typically argue that the failure of a zoning board to grant a use or dimensional variance is a taking without compensation, or that the denial of the statutorily-prescribed variance remedy is arbitrary and capricious in that it lacks a reasonable relation to the public welfare and thus constitutes a denial of substantive due process. In making the latter claim, the plaintiff, under the authority of Monroe v. Pape, 365 U.S. 167 (1961), need not be concerned about utilizing the statutorily-prescribed appeal which under state law is often the "exclusive remedy." See, e.g., MASs. GEN. LAws ANN. ch. 40A, $\S 17$ (West 1979). Although such exclusive judicial remedies may provide for de novo review, it would seem that they should not come within the narrow exception to the judicial exhaustion rule of Dillard v. Virginia Indus. Comm'n, 416 U.S. 783 (1974), since the readily available ministerial judicial remedy of Dillard involved no determination on the merits, but merely reinstatement of compensation due pending a full administrative hearing on the merits. Id. at 784.

105. City of Columbus v. Leonard, 443 U.S. 905, 908-10 (1979) (mein.) (Rehnquist, J., jomed by Burger, C.J., and Blackmun, J., dissenting). 
the "no exhaustion" rule should be limited to inadequate state remedies, or at least should not be applied where plaintiff has initially invoked an optional state administrative remedy but not pursued it to its judicial conclusion. ${ }^{106}$ Whether or not a majority of the Court comes to embrace this view expressly, they already have done so implicitly through the application of the various abstention doctrines. Abstention may be the name, but exhaustion is the game.

\section{II \\ Pullman Abstention-Postronement of the Federal Questions}

The Pullman doctrine ${ }^{107}$ generally requires that federal courts postpone decision of a case presentimg constitutional ${ }^{108}$ issues if resolution of them might be avoided by a state court decision of an uncertain state law question.

\section{A. Pullman Abstention}

In Railroad Commission v. Pullman Co., ${ }^{109}$ the Supreme Court held that the district court should not have enjoined enforcement of a Texas Railroad Commission order that prohibited operation of sleeping cars in the charge of black porters, and required that the cars be in the charge of a Pullman conductor, each of whom was white. Plaintiffs had requested the injunction on the grounds that the order violated the fourteenth amendment and the commerce clause and exceeded the Commission's power under Texas law. ${ }^{110}$ The Court ordered the trial court to stay its hand, holding that "a federal court of equity [should not proceed where it] is asked to decide an issue by making a tentative answer which may be displaced tomorrow by a state adjudication." 111 Underlying the Pullman decision were the two policies of avoidance of

106. Id. at 909-10 (dissenting opinion). As precedent for the latter gloss, Justice Rehnquist cites Huffman v. Pursue, Ltd., 420 U.S. 592 (1975), where the failure of the plaintiff to pursue fully a previously initiated judicial remedy resulted in Younger abstention when he turned to a federal court for relief. See also Gibson y. Berryhill, 41] U.S. 564, 577 n.16 (1973) (suggesling that de novo judicial review of biased administrative proceedings is not an adequate remedy for Younger purposes).

107. An excellent and exhaustive analysis of Pullman abstention appears in Field, Abstention in Constitutional Cases: The Scope of the Pullman Abstention Doctrine, 122 U. PA. L. REv. 1071 (1974).

108. Pullman abstention is not applicable if the federal questions do not involve constitutional issues. Propper v. Clark, 337 U.S. 472, 490 (1949). But see Field, supra note 107, at 1136-38 (arguing that this requirement is not sound).

109. 312 U.S. 496 (1941).

110. Id. at 497-98.

111. Id. at 500 . 
unnecessary decision of federal constitutional issues ${ }^{112}$ and respect for the final authority of state courts to announce state law. ${ }^{13}$ Thus, federal courts should invoke Pullman abstention if the resolution of an unsettled state law issue is necessary to decide the federal constitutional issue.

In practice Pullman abstention is consistent with its two underlying justifications. Thus, a federal court exercising Pullman abstention merely postpones its jurisdiction pending resolution of the unsettled issue of state law, ${ }^{114}$ thereby ensuring that unavoidable federal questions are decided in federal court. The trial court should invoke Pullman abstention where appropriate, sua sponte if necessary, ${ }^{115}$ even in a damages action between private parties, and regardless of the statutory basis of jurisdiction. ${ }^{116}$ The decision to abstain is not discretionary, ${ }^{117}$ despite the Pullman Court's suggestions to the contrary. ${ }^{118}$

The question of whether to invoke Pullman abstention ought to be considered in inost land use cases in federal court, because these cases will usually involve both state law and federal constitutional issues. The threshold question in such cases is whether the case presents a state

112. See Ashwander v. Tennessee Valley Auth., 297 U.S. 288, 341 (1936) (Brandeis, J., concurring); Siler v. Louisville \& N. R.R., 213 U.S. 175, 193 (1909).

In Siler plaintiff requested an injunction against enforcement of a Kentucky railroad cominission order on the grounds that the act creating the commission violated the federal Constitution and that the commission's order exceeded the authority delegated to it by the Kentucky statute. The Supreme Court held that in cases presenting questions of both state law and federal constitutional law, courts should decide the state law questions first, which in some cases would then make decision of the constitutional questions unnecessary. To carry out this principle the Supreine Court construed the state statute at issue, since the highest state court of Kentucky had not done so. Id. at 194. The relationship between Pullman and the Ashwander-Siler principle is not always understood. See, e.g., Bambu Sales, Inc. v. Gibson, 474 F. Supp. 1297, 1302 (D.N.J. 1979) (trial court "abstaim[ed]" from deciding a potentially dispositive state/local preemption issue, apparently on Pullman grounds, and then decided the federal constitutional issue adversely to the municipality).

113. Even before Pullman, some lower federal courts had suggested that they should not pass on a pendent claim that a local regulation was ultra vires until state judicial remedies for the resolution of such questions liad been exhausted. See Morrison v. Pettigrew, 14 F.2d 453, 456 (E.D.N.Y. 1926).

114. Often postponement ends federal jurisdiction, either because the plaintiff wins on the state law issue or has it resolved in a manner that renders the federal constitutional issue moot.

115. See Wisconsin v. Constantimeau, 400 U.S. 433, 437 (1971) (Court considered Pullman abstention although the state did not raise the issue); $c f$. Ohio Bureau of Employment Servs. v. Hodory, 431 U.S. $471,480 \mathrm{n} .11$ (1975) (Court considered abstention at request of amicus curiae).

116. See 17 C. WRIGHT, A. Miller \& E. CoOper, supra note 87, § 4242, at 453, 465-67 (citing cases).

117. See Babbitt v. United Farm Workers Nat'l Umon, 442 U.S. 289, 305-12 (1979) (district court decision not to abstain reversed without any discussion of an abuse of discretion); Bellotti v. Baird, 428 U.S. 132, 146-52 (1976) (same). The nondiscretionary character is misunderstood. See, e.g., McKnight v. Southeastern Pa. Transp. Auth., 583 F.2d 1229, 1240-4l (3d Cir. 1978) (abuse of discretion standard); Ranclıo Palos Verdes Corp. v. City of Laguna Beach, 547 F.2d 1092, 1095 (9th Cir. 1976).

118. 312 U.S. at 500-01. 
law issue, resolution of which might avoid the federal constitutional question. This question may not have a clear answer. The state law issue may arise because the plaintiff pleads a pendent claim that alleges a violation of state law as an alternative ground for relief, ${ }^{19}$ in which case further analysis as to the propriety of Pullman abstention is clearly correct. Even if plaintiff does not plead a state law claim, a state law issue may be implicit. For example, the plaintiff may assume the validity of the statute, regulation, or official act, but the federal trial court may choose to recognize the potential error of that assumption, in effect creating a pendent state claim ${ }^{120}$ necessitating further analysis.

After determination that there is a state law question, the analysis should turn to the uncertamties that surround the state law issue. If the state court has spoken im a maimer sufficiently authoritative to permit the conclusion that the federal question is unavoidable, the federal court should not abstam. ${ }^{121}$ Otherwise, the federal court should postpone the federal constitutional decision to permit the parties to determine the state law authoritatively, unless the cost of doing so would be excessive. ${ }^{122}$

\section{B. Clarity of State Law}

The most cominon problem in Pullman abstention is whether the state law is sufficiently clear to permit the federal court to dispose of it and address the federal question. For example, some federal courts consider the state law outcome of an "as apphed" zoning challenge to be inherently unclear. ${ }^{123}$ Such a conclusion is plausible because the state substantive law applicable to "as applied" challenges is so disparate, ${ }^{124}$ making it extremely difficult to apply the law to cases of first impression.

Courts in land use cases should consider carefully whether the

119. E.g., Stallworth v. City of Monroeville, 426 F. Supp. 236, 240 (S.D. Ala. 1976).

120. Sederquist v. City of Tiburon, 590 F.2d 278, 282 (9th Cir. 1978); Rancho Palos Verdes Corp. v. City of Laguna Beach, 547 F.2d 1092, 1095 (9th Cir. 1976); County Utils. Corp. v. Hampton Rds. Sanitation Dist., 402 F. Supp. 1014, 1016 (E.D. Va. 1975); see Muskegon Theatres, Inc. v. City of Muskegon, 507 F.2d 199, 204 (6th Cir. 1974) (failure to claim violations of state law does not by itself defeat abstention, simce otherwise litigants could frustrate the pohcies underlying the abstention doctrines).

121. It is unclear how ambiguous the state law must be in order to require Pullman abstention. Compare Wisconsin v. Constantineau, 400 U.S. 433, 438-39 (1971) (unambiguous statute held unconstitutional although never interpreted by state court) with Reetz v. Bozanich, 397 U.S. 82, 86-87 (1970) (abstention ordered since state court "could conceivably" interpret previously uninterpreted state constitutional provision so as to avoid federal constitutional issue).

122. The potentially excessive costs most usually implicated are delay and expense. Where first aniendment interests are involved, the price may be too high. See, e.g., Babbitt v. Unitcd Farm Workers Nat'l Union, 442 U.S. 289, 316 (1979) (Brennan, J., dissenting).

123. See Sederquist v. City of Tiburon, 590 F.2d 278, 282 (9th Cir. 1978).

124. See C. HaAr, land Use Planning 292 n.46 (3d ed. 1979). 
state law is unclear, lest they err as the court did in Steel Hill Development, Inc. v. Town of Sanbornton. ${ }^{125}$ Plaintiff sought a federal declaratory judgment that the regulations rezoning its land to increase minimum lot sizes from 3,500 square feet to three and six acres (large lot zoning) constituted a taking and violated due process. Defendant town moved for judgment on the pleadings. The court found Pullman abstention mappropriate, holding that the pleadings raised no preliminary question of state law, that the state and federal constitutional issues were "essentially "the same," and that the state law was "not unclear." 126 Not only is the first proposition inconsistent with the other two, but each is dubious standing alone. The failure to plead pendent state claims is not conclusive for Pullman purposes. ${ }^{127}$ Moreover, the commonahity of the taking issue under the state and federal constitutions requires a case-by-case analysis, and cannot be assumed; ${ }^{128}$ it was not clear here that the state law was settled.

The court's subsequent decision on the merits ${ }^{129}$ demonstrates the error of the earher decision not to abstain. The second decision considered the vahidity of the challenged regulations under New Hainpshire's enabling act. ${ }^{130}$ Although the court purported to invoke New Hampshire law as to whether the defendant's amended regulations comported with the enabling act's mandates, none of the cases cited ${ }^{131}$ treats either the taking or the enabling act issue in the context of large lot zoning. Smce no subsequent New Hampshire court has decided this question decisively, ${ }^{132}$ the law of that state on this controversial question remains in doubt. But the court did not perceive these difficulties

125. 335 F. Supp. 947 (D.N.H. 1971).

126. Id. at 952 (citing Lerner v. Town of Islip, 272 F. Supp. 664 (E.D.N.Y. 1967)).

127. See cases cited at note 120 supra.

128. See text accounpanying notes $139-55$ infra.

129. 338 F. Supp. 301 (D.N.H.), affd, 469 F.2d 956 (1st Cir. 1972).

130. N.H. REv. STAT. ANN. $\S 31: 60$ (1970). This consideration suggests a de facto adherence to the principle of avoiding unnecessary decision of federal constitutional issues, and is at odds with the court's disclaimers in the earlier decision regarding the presence of preliminary state issues.

131. Sibson v. State, 111 N.H. 305, 282 A.2d 664 (1971) (large lot zoning, but taking issue stemmed from Port Authority's alleged wrongful assumption of jurisdiction over the land); City of Keene v. Blood, 101 N.H. 466, 146 A.2d 262 (1958) (residential zoning restriction applied); Rockinghain Hotel Co. v. Town of North Hampton, 101 N.H. 441, 146 A.2d 253 (1958) (sign ordinance upheld).

132. New Hampshire law is unclear as to how far a municipality inay go in furthering goals of conservation and future orderly development at the expense of present economic development. Compare Bosse v. City of Portsmouth, 107 N.H. 523, 529, 226 A.2d 99, 105 (1967) (zoning restriction preserving property for possible future use leeld valid), with Kimball v. Blanchard, 90 N.H. 298, 300, 7 A.2d 394, 396 (1939) (regulation preserving property for future use did not pronote proper purpose). The only case subsequent to Steel Hill to involve an increase in ininimunu lot size is R.A. Vachon \& Son v. City of Concord, 112 N.H. 1077, 289 A.2d 646 (1972), where the court avoided directly addressing the taking issue. 
in determining the state law, and thus incorrectly refused to order abstention. ${ }^{133}$

\section{State Constitutional Questions}

One troublesome problem is whether Pullman abstention is required where the state law issue concerns the state constitution rather than a state statute. ${ }^{134}$ The conventional approach has been to focus on the nature of the state constitutional provision. If the provision is unique, then abstention is required. If it is sufficiently analogous to-if it mirrors-the corresponding federal constitutional provision then a federal court familiar with the federal counterpart may inake an authoritative determination, and avoid abstention. ${ }^{135}$ This type of analysis merely obscures the real issue: Is the state law unclear?

The determinative issue should not be whether the state constitutional provision mirrors the federal provision, but rather the state court's construction of the state provision's language. In some cases, no uncertainty surrounds the construction of the state constitutional provision, because there is only one construction of the state constitutional

133. Possibly the court failed to perceive the difficulties in determining the state law because counsel may not have contributed all that it could to the decision. In Steel Hill, for example, the most persuasive argument for abstention would have required the defendant to urge the possibility that a state court might find the ordimance invalid under the enabling act or the state constitution - a position that the town would understandably be reluctant to pursue with any vigor.

134. One source of the problem is the difficulty in reconciling a series of decisions culminating with Askew v. Hargrave, 401 U.S. 476 (1971), and Harris County Comm'rs Court v. Moore, 420 U.S. 77 (1975). The earlier decisions were Wisconsin v. Constantimeau, 400 U.S. 433 (1971); Reetz v. Bozanich, 397 U.S. 82,87 (1970) (Pullman abstention ordered where state constitutional provision related to "fish resources, an asset unique in its abundance in Alaska"); Meridian v. Southern Bell Tel. \& Tel. Co., 358 U.S. 639 (1959) (Pullman abstention ordered to resolve vahidity of a state statute under state constitutional counterpart of art. $1, \S 10$, without diseussion of whether the state provision mirrors the federal provision). In Constantineau the Wisconsin Constitution had no linguistic counterpart to the federal due process clause. However, the Wisconsin Suprenie Court had leeld that art. $1, \S 1$ of its constitution inposed substantially equivalent liunitations on state action. 400 U.S. at $440 \mathrm{n} .1$ (Burger, C.J., dissenting). No opinion discussed the nirroring problem, and the Court refused to abstain. In Askew the plaintiffs in the federal action relied exclusively on the federal equal protection clause. Subsequent to the filing of the federal suit, plaintiffs commenced a state court action that charged violations of the Florida Constitution. The Court noted the existence of the state suit and ordered Pullman abstention without discussion of the nature of the state constitutional issues raised by the state suit. 401 U.S. at 477-78. In Moore the state constitutional provision concerned mechanisms for removal of county officers. Claiming to imvoke Pullman abstention, the Court ordered dismissal rather than postponement of the federal suit in order to avoid the effect of state court decisions that precluded Texas trial courts from granting declaratory relief while a federal court retains jurisdiction over the federal claim. 420 U.S. at $88-89$ \& n. 14.

135. See Developments in the Law-Section 1983 and Federalism, 90 HARv. L. Rev. 1133, 1256 n.34 (1977) [hereinafter cited as Developments]. But cf. Hoine Builders Ass'n v. City of Kansas City, 379 F. Supp. 1316, 1318-19 (W.D. Mo. 1974) (unclear opimion apparently, and incorrectly, suggesting that existence of state constitutional issue, without more, requires Pullman abstention). 
provision that would not violate the federal constitution. ${ }^{136} \mathrm{Or}$, although the mirrored state constitutional provision may be subject to more than one construction, the state courts may have made a practice of following the construction of the federal constitutional provision, thus effectively abdicating the role of final arbiter of that provision. ${ }^{137}$ Courts should not invoke Pullman abstention in such cases. In other cases, despite the mirroring, the state court interpretation may differ critically from the federal construction. ${ }^{138}$ In such cases, the federal court should abstain if the state constitutional issue is unclear and might be decided in a manner permitting avoidance of the federal constitutional issue.

The federal courts have often struggled with the imterpretation of state constitutions im applying Pullman abstention principles to inverse condemnation and taking cases. The issue under both the state and federal constitutions may be whether a "taking without just compensation" has occurred, but it is possible that the court should nonetheless abstain. First, the state due process clause may be influenced by the older, now discarded, federal due process theories, and thus effectively be more restrictive of state pohce power than its federal counterpart. ${ }^{139}$ Second, the property subject to the taking may be defined differently under state law than under the federal constitution. Thus, in Rancho Palos Verdes Corp. v. City of Laguna Beach, ${ }^{140}$ the Nimth Circuit apphed Pullman abstention principles to a section 1983 action for mjuries to plaintiff's property rights caused by imposition of a building moratorium. Although certam counts in the complaint alleged only federal constitutional deprivations, the court held that the equal protection and due process challenges imght depend on underlymg questions of state law. The court found that a determination under state law of the existence of a property interest protected by the federal constitution was essential to mamtenance of the federal constitutional claim. Simce it

136. Developments, supra note 135 , at 1256.

137. See, e.g., Delaware v. Prouse, 440 U.S. 648, 652-53 (1979) (state court felt compelled to construe the state provisions as coextensive with the federal provision, thus foreclosing the existence of an independent state constitutional ground for decision).

138. See, e.g., People v. Brisendine, 13 Cal. 3d 528, 545-52, 531 P.2d 1099, 1110-15, 119 Cal. Rptr. 315, 326-31 (1975) (language in California Constitution essentially identical to fourth amendment, yet interpreted more broadly). Harder cases are exeinplified by Minnesota v. National Tea Co., 309 U.S. 551 (1940), where although the state court decision is seemingly predicated on federal law, it may have been decided on an independent state ground. The inclination of a state court to accept the federal gloss might be sufficient to preclude the necessity for Pullman abstention, since such an inclination means that the federal courts' interpretation would be accepted by the state courts, and that, therefore, the state constitutional provision cannot be unclear.

139. See East Coast Lumber Terminal, Inc. v. Town of Babylon, 174 F.2d 106, 111 (2d Cir. 1949) (affirming abstention order and noting that New York Constitution may be more restrictive than the fourteenth amendment).

140. S47 F.2d 1092 (9th Cir. 1976). 
was unclear whether plaintiff had such a property right under state law, the court held that the trial court was within its discretion to invoke Pullman abstention to permit state court resolution of that issue. ${ }^{141}$

Even if the substantive scope of state and federal constitutional provisions is similar, critical reinedial differences may exist. The federal district court in Donohoe Construction Co. v. Maryland-National Capital Park \& Planning Commission ${ }^{142}$ did not perceive this point. There plaintiffs sought declaratory relief and dainages for an implied taking caused by defendant's land use regulations. The court concluded that Pullman abstention was inappropriate, smce the state law question arose out of a mirrored state constitutional provision. ${ }^{143}$ The court rejected the claim that it should abstain because there was a parallel proceeding in state court concerning the same state constitutional issue. ${ }^{144}$ It reasoned that the substantive scope of the Maryland taking clause was the same as with the federal clause, although it acknowledged that plaintiffs in the federal case sought compensation under a theory of inverse condemnation, whereas in the state proceedings they sought injunctive relief.

The Donohoe court was incorrect in concluding that the federal and Maryland constitutional law of takings were essentially the same, since it ignored the remedial implications of the respective constitutional provisions. ${ }^{145}$ Although the language of the respective provi-

141. Id. at 1095; accord, McKnight v. Southeastern Pa. Transp. Auth., 583 F.2d 1229, 1240-41 (3d Cir. 1978). But sce Monaghan, Of "Liberty" and "Property," 62 CoRnell L. Rev. 405, 434-43 (1977) (although interests are created by state law, their characterization as property for due process purposes should be determined by federal standards).

142. 398 F. Supp. 21 (D. Md. 1975), rev'd on other grounds sub nom. Donohoe Constr. Co. v. Montgomery County Council, 567 F.2d 603 (4th Cir. 1977).

143. 398 F. Supp. at 29-30.

144. Because of the pending state cases involving the same property, Donohoe could today be treated as a civil-Younger case. See text accompanying notes 272-84 infra.

145. The court's conclusion that the federal and Maryland constitutional law of takings without jnst compensation are the same, and that therefore the state's law recognizes the inverse condemnation remedy for takings, $398 \mathrm{~F}$. Supp. at 29-30, is dubious. Although there are Maryland cases that broadly state that its law follows federal law, see Bureau of Mines v. The George's Creek Coal \& Land Co., 272 Md. 143, 156, 321 A.2d 748, 755 (1974); Allied Am. Mutual Fire Ins. Co. v. Commissioner of Motor Vehicles, $219 \mathrm{Md}$. 607, 615-16, 150 A.2d 421, 426-27 (1959), the cases cited by the court do not consider the inverse condemnation issue. No Maryland case has upheld an award of compensation for the taking of property by virtue of a police power land use regulation. See Leet v. Montgoinery County, 264 Md. 606, 287 A.2d 491 (1972) (regulation that constitutes a taking is unenforceable); Sanderson v. Mayor \& City Council, 135 Md. 509, 523, 109 A. 425, 430 (1920) (classic eninent domain issue). The only case cited by the court that considered the issue of damages was Arnold v. Prince George's County, 270 Md. 285, 296, 311 A.2d 223, 229 (1973) (denying relief where the police power at issue was the designation of a proposed road on a master plan-an eminent domam problem). Cf. Leet v. Montgomery County, $264 \mathrm{Md}$. at 615 n.3, 287 A.2d at 497 n.3 (dictnm) (inverse condemnation requires that property owner's imjury be connected to the construction or operation of a public enterprise). 
sions is similar, ${ }^{146}$ such that courts often confuse the terms, there is nevertheless a profound difference between a taking case and an inverse condemnation action. The former challenges the validity of a pohice power regulation on the ground that it has an excessive economic impact, and seeks to invalidate the regulation. ${ }^{147}$ The latter assumes a valid exercise of the eminent domain power, but seeks to require payinent for the resulting decrease in value. ${ }^{148}$ If the state constitution were to require invalidation of the regulations, the federal court would avoid deciding the constitutional issue of whether a regulation that violates the taking clause requires the payment of inonetary compensation. The threshold state constitutional determination, if unclear, should be decided by state courts. Thus, since the Maryland constitutional provision was not clear, Donohoe presented the classic Pullman case. The construction of the state constitution by the state court would either have obviated the necessity for deciding the federal constitutional issue or drastically altered its contours. ${ }^{149}$

146. Compare U.S. CoNsT. amend. V ("[N]or shall private property be takeu for public use, without just compensation") with MD. CoNST. art. III, $\S 40$ ("The General Assembly shall enact no law authorizing private property to be taken for public use without just compensation, as agreed upon between the parties, or awarded by a Jury, being first paid or tendered to the party entitled to such compensation"). The theory of inverse condemnation is "impossibly muddled." D. MANDElker, Managing the URBan ENVIRONMENT 622 (2d ed. 1970).

The difficulty stems from the language of state constitutions which provide that compensation must be paid for 'property' that has been 'taken,' or that has been 'taken or damaged' by public agencies. Courts attempting to explam a recovery under these provisions may concentrate on an analysis of the property interest that is alleged to liave been taken, or may explore instead the question of whether a taking, or a taking or damaging, has in fact occurred.

Id.

147. Several courts have suggested that if the gravamen of the complaint in an "implied taking" case is that the regulatory schcme is an invalid exercise of the police power, a declaration of invalidity is the only appropriate remedy. San Diego Gas \& Elec. Co. v. City of San Diego, 48 U.S.L.W. 3814 (U.S. 1980); Agins v. City of Tiburon, 24 Cal. 3d 266, 273-78, 598 P.2d 25, 28-32, 157 Cal. Rptr. 372, 375-79 (1979), affd on other grounds, 100 S. Ct. 2138 (1980); Fred. F. Frencl Investing Co. v. City of New York, 39 N.Y.2d 587, 593-94, 350 N.E.2d 381, 385, 385 N.Y.S.2d 5, 8, appeal dismissed and cert. denied, 429 U.S. 990 (1976). Eminent domain compensation is proper only where the appropriate authority lias purported to exercise the eminent domaim power. To treat a purported excrcise of the police power as a de facto exercise of the eminent domain power is to ignore the state statutory and constitutional restraints on the exercise of the eminent domain power and to impose unauthorized costs on the state or local government involved.

148. If an enactment takes the form of regulation, its effect might be excessive in due process terms, but the regulation might nevertheless perform an important public function for purposes of eminent domain, thus justifying compensation if the legislative body was trying to exercise the eminent domain power. See Beuscher, Some Tentative Notes on the Integration of Police Power and Eminent Domain by the Courts: So-Called Inverse or Reverse Condemnation, 1968 URB. L. ANN. 1.

149. For example, if the state court had invalidated the regulation, the quantum of damages recoverable in the federal case wonld have been drastically reduced, even assuming that damage due to delay in such circumstances would be compeusable under the federal Constitution. See text accompanying notes 63-67 supra.

of course, in a state such as Califormia, where the paynent of compensation has been held 
In most cases where the plaintiff seeks rehef under both federal and state constitutional provisions that limit the power of the state to restrict the use of private land, a suit in federal court for damages under an inverse condemnation theory probably should be subject to Pullman abstention. Even assuming that the only state law issue arises under the state constitution, ${ }^{150}$ and that the state constitutional provision mirrors the fifth ainendment, ${ }^{151}$ in the absence of authoritative construction of the state constitutional provision, a federal court should abstain because of the potential for a different construction of the respective provisions, especially with respect to remedy. ${ }^{152}$

In cases in which the rehef sought in federal court is merely a declaration that a zoning ordinance is invahd because it constitutes a taking without compensation, the case for Pullman abstention is less persuasive. ${ }^{153}$ The state law may be clear and correspond with the federal law. ${ }^{154}$ But the plaintiff, although avoiding Pullman abstention, gains little advantage. Such cases almost invariably result in a judginent for the defendant on the taking claim, and thus the result is not only a refusal of Pullman abstention, but either dismissal for lack of a substantial federal question or at least dismissal of the pendent state claims. $^{155}$

not to be appropriate, see Agins v. City of Tiburon, 24 Cal. 3d 266, 598 P.2d 25, 157 Cal. Rptr. 372 (1979), aff'd on other grounds, 100 S. Ct. 2138 (1980), the state law would not be unclear in this respect, and abstention, therefore, may not be called for.

150. In many such cases, this is a dubious proposition in light of the rule that limits the exercise of zoning power by a local municipality to purposes enumerated in the enabling act. See generally 1 R. ANDERSON, supra note 86, at $\$ \$ 2.15-.25$ (2d ed. 1976).

151. The constitutions of 23 states lave language that is broader than the fifth amendment, in that they require compensation when private property is either taken or damaged for public use. See Note, Inverse Condemnation: Its Availability in Challenging the Validity of a Zoning Ordinance, 26 StAN. L. Rev. 1439, 1439 n.3 (1974).

152. Without making any distinctions based on the nature of the remedy, the Ninth Circuit, relying on Reetz v. Bozanich, 397 U.S. 82 (1970), took the position that the existence of mirrored provisions nuade Pullman abstention "particularly appropriate." Newport Invs., Inc. v. City of Laguna Beach, 564 F.2d 893, 894 (9th Cir. 1977) (per curiam). That position was repudiated in Pue v. Sillas, 632 F.2d 74, 80-81 (9th Cir. 1980). The reliance on Reetz was nisplaced since the state constitutional provision at issue there was unique, not inirrored. 397 U.S. at 87. Compare Sixth Caniden Corp. v. Township of Eveshan, 420 F. Supp. 709, 729 (D.N.J. 1976) (Pullman abstention rejected on the authority of Donohoe despite the court's subsequent assertion that "federal and [New Jersey] standards for zoning cases . . . are not identical").

153. Even in this type of case, some courts have indicated they would abstain to permit statc proceedings to run their course. See Sixth Camden Corp. v. Township of Evesham, 420 F. Supp. 709,719 (D.N.J. 1976). It is not at all clear that the court would have reached this result if a statc court judicial challenge had not been pending. If not, the result would really be a form of Younger or Colorado River abstention since the pendency of the state rcmedy is irrelevant for Pullman abstention. If the pendency of the state judicial proceeding in cases like Sixth Camden was not the key, then the result was correct only if the statutory standard for granting variances did not parrot the fourteenth ainendment standard.

154. E.g., Lerner v. Town of Islip, 272 F. Supp. 644, 666-67 (E.D.N.Y. 1967).

155. See text accompanying notes 60-62 supra. 


\section{Adequacy of State Remedies}

Generally, federal courts declare that they will not invoke Pullman abstention unless plaintiffs have an adequate state reinedy. ${ }^{156}$ This requireinent seems logical and fair if the plaintiff's asserted federal rights are not to be sacrificed to Pullman considerations. However, because Pullman abstention presupposes the potential for return to the federal forum, ${ }^{157}$ the relevant imquiry into the adequacy of the state reinedy differs from the superficially analogous question posed in other contexts; there the adequacy of the state remedy depends on whether it will afford plaintiff all the relief to which he is legally entitled in the vimdication of the federal claim. For Pullman abstention, the test of adequacy should be the state court's potential for resolving unsettled questions of state law. ${ }^{158}$ Certification procedures, where available, directly address this need, ${ }^{159}$ as may a pending state suit. ${ }^{160}$ If neitler is available, resolution of the unclear state law issues may be difficult.

Declaratory relief, in jurisdictions that provide for this remedy,

156. This requirement derives from language in Pullman. 312 U.S. at 501.

157. England v. Louisiana State Bd. of Medical Examimers, 375 U.S. 411, 416 (1964). But see Home Builders Ass'n v. City of Kansas City, 379 F. Supp. 1316, 1319 (W.D. Mo. 1974) (dismissing the federal action on Pullman grounds). The delay inherent in the Pullman procedure usually results in the plaintiff voluntarily abandoning the federal forum by submitting all issues to the state court for determination. See Field, The Abstention Doctrine Today, 125 U. PA. L. Rev. 590, 591 (1977). One troublesome problem that has arisen because of the postponement attaching to Pullman abstention is whether it is appropriate for the abstaining trial court to grant interlocutory rehef. Such courts are reluctant to grant injunctive rehef because it requires that plaintiff demonstrate a substantial likelihood of success on the merits. Such an inquiry would force the trial judge to violate the Pullman principles of avoiding premature decision of federal constitutional issues and of favoring state court determination of state law issues. See generally Wells, Preliminary Injunctions and Abstention: Some Problems in Federalism, 63 CoRnell L. Rev. 65 (1971).

158. This distinction has eluded trial courts in land use controversies, where the test of adequacy often seems to be whether the state courts provide a daunages remedy for injuries the landowner has sustaimed. See Muskegon Theatres, Inc. v. City of Muskegon, 507 F.2d 199, 205 (6th Cir. 1974); Donohoe Constr. Co. v. Maryland-Nat'l Capital Park \& Planning Comm'n, 398 F. Supp. 21, 27, 30 (D. Md. 1975), rev'd on other grounds sub nom. Donohoe Constr. Co. v. Montgomery County Council, 567 F.2d 603 (4th Cir. 1977); Jim Young Dev. Corp. v. State Highway Comm'n, 56 F.R.D. 38, 44, 45 (W.D. Mo. 1971). Possiby this issue confuses the courts because a case such as Jim Young involves both Pullman and Burford abstention, thus potentially calling for dismissal rather than postponement.

The concern for remedial sufficiency rather than ability to resolve unclear questions of state law is also evidenced by the unwillingness to invoke Pullman abstention in cases that involve personal liberties rather than property rights. See Babbitt v. Umited Fann Workers Nat'l Union, 442 U.S. 289, 316-17 (1979) (Brennan, J., dissenting); Harmon v. Forssenius, 380 U.S. 528, 537 (1965); Baggett v. Bullitt, 377 U.S. 360, 378 (1964).

159. See, e.g., Bellotti v. Baird, 428 U.S. 132, 150-52 (1976).

160. See, e.g., Harris County Comm'rs Court v. Moore, 420 U.S. 77, 82 (1975); Askew v. Hargrave, 401 U.S. 476, $477-78$ (1971) (per curiain); cf. Gibson v. Berryhill, 411 U.S. 564, 580-81 (1973) (uncertainty as to scope of previously pending state proceeding noted as possibly warranting federal court deference to the state proceeding); Isthmus Landowners Ass'n v. California, 601 F.2d 1087, 1089 (9th Cir. 1979) (per curiam) (filing of suit held to toll state statute of limitations and permit previously pending state suit to be reinstated). 
would seem to be the answer. However, the use of the England procedure, ${ }^{161}$ which allows the plamtiff to reserve from state court adjudication his federal constitutional claims so that he may return to federal court to hitigate them, may im some cases violate state constitutional provisions prohibitimg advisory opimions. ${ }^{162}$ The advisory opinion problem is less likely to arise if procedures other than declaratory rehef are employed to decide the state law issues. For example, state statutory appeals procedures might more plausibly address only the state law issues and exclude from consideration the constitutional questions. ${ }^{163}$

One problem with utilizing state statutory appeals procedures is that the apphicable statutes of limitations inay bar resort to them by the time of the abstention decision. If so, the state remedy is inadequate unless the untimely appeal can be entertained as a matter of discretion. ${ }^{164}$ This suggests, however, that a plaintiff, by his own lack of dihgence in pursuing available state remedies, inight force the federal court to forego abstention. Such an outcome is troubling, and may suggest that the courts should not be so forced in such circumstances. ${ }^{165}$

In some cases the adequacy of the state remedy problem may be comphicated further by state law administrative exhaustion rules, and limitations upon the nature of the questions that may be raised before administrative agencies. The court in Lister v. Lucey ${ }^{166}$ held that the requirement that plaintiffs resort to administrative and legislative appeals before state court decision of the unclear state law made Pullman

161. In England v. Louisiana State Bd. of Medical Examiners, 375 U.S. 411 (1964), the Court addressed the potential res judicata problein that confronts a federal plaintiff returning to the state courts. The plaintiff should indicate to the state court what his federal claims are, so that the court can decide the state issues in light of those clains. If the plamtiff then indicates that he reserves his federal claims, he inay return to federal court if he loses on the state law issues. Id. at 421. This proeedure allows the federal district court to perform the factfinding function. Id. at 416-17.

162. See, e.g., United Servs. Life Ins. Co. v. Delaney, 396 S.W.2d 855, 861 (Tex. 1965); ac. cord, Tsongas v. Secretary, 362 Mass. 708, 714, 291 N.E.2d 149, 153 (1972); In re Richards, 223 A.2d 827 (Me. 1966) (court refused to answer certified questions from district court because facts were in doubt, and thus any opinion would be an advisory opinion). The Supreme Court accommodated the Delaney holding in Harris County Comm'rs Court v. Moore, 420 U.S. 77, 88 n.14 (1975), disunissing rather than postponing a Pullman case.

163. See Gumley v. Board of Seleetmen, 371 Mass. 718, 358 N.E.2d 1011, 1014 (1977) (deciding state law issues arising from the application of an historic districts act by way of "exclusive" statutory appeal procedure despite the existence of explicit federal constitutional claims). Compare Gumley with Tsongas v. Secretary, 362 Mass. 708, 714, 291 N.E.2d I49, 153 (1972) (deelaratory relief on state constitutional question withheld because state court answer would be an advisory opinion since plaintiff had reserved sinilar fedcral constitutional question).

164. See, e.g., Silverman v. Browning, 359 F. Supp. 173, 176 (D. Conn. 1972) (three-judge court), aff'd, 411 U.S. 941 (1973).

165. $C f$. Huffinan v. Pursue, Ltd., 420 U.S. 592, 608 (1975) (Younger abstention appropriate even though state reinedy no longer available because of plaintiffs lack of diligence).

166. 575 F.2d 1325 (7th Cir.), cert. denied, 439 U.S. 865 (1978). 
abstention inappropriate. ${ }^{167}$ This conclusion seens to confuse the "adequacy to clarify the law" and the "adequacy to grant a complete remedy" issues. State law administrative exhaustion rules slow the clarification process, but if, as is usual, there is a right of appeal after termination of the nonjudicial proceedings, then the state courts would still be able to clarify the state law, although only after considerable delay.

\section{E. Sensitive State Law Questions}

Whether the state law question in a Pullman analysis is a sensitive one or not should play no part in the abstention decision. The Pullman Court suggested that abstention is appropriate only with respect to state law questions of a "sensitive" nature. ${ }^{168}$ Subsequent Supreme Court decisions have not developed this suggestion, ${ }^{169}$ but soine lower courts have inade "sensitivity" part of the litmus test for Pullman abstention. Such a conclusion is a plausible, but not a preferable, imterpretation of the Pullman Court's statement that abstention may avoid "needless friction with state policies . ..."170 One of the policies enumerated was preservation of "the final authority of a state court to interpret doubtful regulatory law of the state." ${ }^{171}$ However, some commentators and courts have chosen to focus attention on the potential for interference with state programs, ${ }^{172}$ with emphasis on such programs' administration, rather than on the more general concept of state policies.

167. Id. at 1331. The court suggested that there should be a general rule against abstention where resort to lengthy nonjudicial proceedings is a prereqnisite to state court determination of the Pullman issues. Id. at 1332. Cf. Seventh Circuit Review Decisions: Augzist 1977 to August 1978, 54 Notre Dame Law. 335, 347 (1979) (arguing that district courts should be required to make a specific finding of fact as to the adequacy of the state remedy in Pullman terms).

The requirement of administrative exhaustion might be more troublesome if the scope of administrative appeals were limited to nonconstitutional issues and the unclear state law issue involved the state constitution. However, most states permit such constitutional issues to be raised after local adıninistrative agency exhaustion. See, e.g., Mountain View Chamber of Commerce v. City of Mountain View, 77 Cal. App. 3d 82, 94-95, 143 Cal. Rptr. 441, 447 (Ist Dist. 1978).

168. 312 U.S. at 498.

169. See Colorado River Water Conserv. Dist. v. United States, 424 U.S. 800, 814 (1976) (per Breunan, J.).

170. 312 U.S. at 500.

171. Id.

172. Thus, Professor Field has stated that Pullman abstention "is impelled by a fear that federal court decision of some state law issues risks improvident interference with a valid state progran or unnecessary decision of a federal constitutional question, or both." Field, supra note 107, at 1090 (1974). One consequence of this insistence on treating the avoidance of interference as a distinct component of Pullman abstention is the suggestion that federal courts should attempt to identify which way they would rule upon the state law issues, since there is no interference with state programs if the courts uphold thein. Id. at 1102-03. A recent line of cases suggests recognition of Field's thesis. See Greenholtz v. Inmates of the Neb. Penal \& Correctional Complex, 442 U.S. 1 (1979) (state statute at issue that Nebraska courts had not construed; statute upheld against constitutional attack); Bishop v. Wood, 426 U.S. 341, 345 (1976) (similar problem, similar result). 
Combining the emphasis on programs with the Pullman Court's references to the "sensitive area of social policy"173 in this manner produces Pullman tests that either elevate sensitivity to an indispensable prerequisite for Pullman abstention ${ }^{174}$ or that apply the unnecessary-constitutional-adjudication and needless-interference tests as though the former were relevant only if it would needlessly interfere, rather than as though it were imdependently important. ${ }^{175}$

In the land use setting, the application of analyses emphasizing the sensitivity of the state policies or programs may produce peculiar results. For example, although section 1983 cases are often thought to be the least likely candidates for abstention, ${ }^{176}$ some section 1983 zoning cases are now falling into the "most likely" category. This happens because zoning cases involve sensitive issues, the improper resolution of which portends mischief for state regulatory programs. Thus, the courts mvoke Pullman abstention for zoning cases. ${ }^{177}$ However, these cases need not depend upon a faulty Pullman analysis. Rather, their einphasis on the propriety of state resolution of local and state problems suggests a reliance on what has become known as Burford abstention.

Arguably, the Court slighted the abstention questions in these cases because its vindication of the state process precluded interference with state programs.

173. 312 U.S. at 498.

174. See D'Iorio v. County of Del., 592 F.2d 681, 686 (3d Cir. 1978) (requiring as a prerequisite for abstention that erroneous decision of state law potentially disrupt "important state policies"); Canton v. Spokane School Dist. No. 81, 498 F.2d 840, 845 (9th Cir. 1974). For land use cases applying the Canton test, see Sederquist v. City of Tiburon, 590 F.2d 278 (9th Cir. 1978); Rancho Palos Verdes Corp. v. City of Laguna Beach, 390 F. Supp. 1004 (C.D. Cal. 1975), affd, 547 F.2d 1092 (9th Cir. 1976).

175. See McKnight v. Southeastern Pa. Transp. Auth., 583 F.2d 1229 (3d Cir. 1978). There, authoritative determination of an unclear state law issue would have perinitted avoidance of a constitutional issue. The court subordinated the avoidance of the constitutional issue thread of Pulman, suggesting that decision of the unclear state law question, and subscquent decision of the constitutional issue if necessary, would not interfere with any sensitive state programs. Id. at 1240-42 (dictum) (citing Field, supra note 107, at 1093-1101).

176. See Canton v. Spokane School Dist. No. 81, 498 F.2d 840, 846 (9th Cir. 1974); Wright v. McMann, 387 F.2d 519, 525 (2d Cir. 1967). Compare Harrison v. NAACP, 360 U.S. 167 (1959) (abstention ordered in $\$ 1983$ challenge), with Mayor v. Educational Equality League, 415 U.S. 605,628 (1974) (Court noted that "abstention is not favored in an equal protection, civil rights case" brought under $\$ 1983$ ).

177. See Isthmus Landowners Ass'n v. California, 601 F.2d 1087, 1091 (9th Cir. 1979) (per curiam); Newport Invs., Inc. v. City of Laguna Beach, 564 F.2d 893, 894 (9th Cir. 1977) (per curiam); Rancho Palos Verdes Corp. v. City of Laguna Beach, 390 F. Supp. 1004, 1005 (C.D. Cal. 1975), aff'd, 547 F.2d 1092 (9th Cir. 1976). 


\section{III \\ BURFORD ABSTENTION-Dismissal OF FEDERAL JURISDICTION}

The second branch of the abstention doctrine is known as Burford abstention. ${ }^{178}$ It differs from Pullman abstention principally in that it is not motivated by any concern over avoiding constitutional decisions. Rather, its thrust is to avoid interference with state policies and programs.

\section{A. The Burford Doctrine}

In Burford v. Sun Oil Co., ${ }^{179}$ a suit premised on both federal question and diversity jurisdiction, the plaintiff sought to enjom the enforcement of an order by the Texas Railroad Commission for the drilling of certain oil wells; the Court held that deference to the state court was proper. It emphasized the complex nature of the Texas regulatory scheme that the federal trial court was being called on to construe, the discretionary nature of the mjunctive power that it was requested to wield, and the adequate, expeditious nature of the state review procedures it was called on to supplant. ${ }^{180}$ Although the majority alluded to the Pullman notion that state courts are the best vehicle for deciding questions of state law, ${ }^{181}$ the facts, disposition, and dissent suggest a different rationale. The state law questions were before the Court by virtue of botli pendent jurisdiction and diversity jurisdiction, situations in which, as the dissent notes, federal courts routmely decide questions involving state law. ${ }^{182}$ More important, unlike Pullman, the Court did not postpone decision pending state court resolution of the state law, but mstead dismissed the case entirely. Thus the Pullman allusion had to be supplanted by a different federalism concern.

Although Burford abstention today represents a sigmificant limita-

178. Neither the Supreme Court nor the lower federal courts have consistently agreed on the number of categories of abstention or the appropriate terminology to describe them. See, e.g., 17 C. Wright, A. Miller \& E. CoOper, supra note $87, \S 4241$, at 446 . With an appropriate caveat as to the differences between them, see, e.g., note 191 infra, I refer to the mvocation of abstention on the basis of either Burford or Louisiana Power \& Light Co. v. City of Thibodaux, see text accompanying notes 187-93 infra, as Burford abstention.

179. 319 U.S. 315 (1943).

180. Id. at $332-34$.

181. Id. at 331-34.

182. Id. at 336-37 (Frankfurter, J., dissenting). Justice Frankfurter began his dissent as follows: "To deny a suitor access to a federal district court under the circumstances of this case is to disregard a duty enjomed by Congress and made manifest by the whole history of the jurisdiction of the United States Courts based upon diversity of citizenship between parties." Six months later Frankfurter at least temporarily had his way on the obligation of federal courts to implement the Erie doctrine with respect to uncertain state law. See Meredith v. City of Wimter Haven, 320 U.S. 228 (1943) (discussed at text accompanying note 190 infra). 
tion on the accessibility of the federal forum, it had little influence for a period of almost two decades. It was virtually ignored until 1951, when in Alabama Public Service Commission v. Southern Railway Co ${ }^{183}$ the Court invoked Burford's authority to abstain in a case involving a specialized statutory scheine for judicial review. Like Burford, jurisdiction in Alabama Public Service was predicated on both diversity and the existence of a federal question, but unlike Burford its facts posed no Pullman problein because there were no unclear issues of state law. ${ }^{184}$ The inajority assuined that Burford authorized a federal court to declime to assert equitable jurisdiction where the controvcrsy involved predominantly local issues and where federal intervention was "not necessary for the protcction of federal rights." 185 Apparently, significant factors leading to this result were the existence of a state statutory appeal mechanisin and the concentration of judicial review in a particular state court. ${ }^{186}$

The application of Burford analysis in land use cases has been soinewhat unclear and imprecise. Two diversity cases involving state eminent doinain proceedings, Louisiana Power \& Light Co. v. City of Thibodaux ${ }^{187}$ and County of Allegheny v. Frank Mashuda Co., ${ }^{188}$ are loosely labeled as Burford-type abstention cases despite several differences from Burford. Decided on the same day, they reached opposite conclusions even though they were based on essentially similar records. ${ }^{189}$ Thibodaux and Allegheny perliaps more accurately represent a limited eminent domain exception to the rule of Meredith $v$. Win-

183. 341 U.S. 341 (1951).

184. Id. at 344 .

185. Id. at $349-50$.

186. Id. at 348 .

187. 360 U.S. 25 (1959). The majority opinion emphasized the special nature of eminent domain. Id. at 28-29.

188. 360 U.S. 185 (1959). The majority opinion does not rely on the special nature of eminent domain, stating that it is not "mystically involved with 'sovereign prerogative." Id. at 192. Although the Court declined to imvoke Burford abstention in Allegheny, Justice Brennan for the first tine appeared to identify it as a separate category of abstention. Id. at 189 (citing Burford for "abstention on grounds of coinity with the States when the exercise of jurisdiction by the federal court would disrupt a state administrative process," and Alabama Public Service for abstention to "otherwise [avoid creating] needless friction by uunecessarily enjoining state officials from executing domestic policies").

189. The court was badly spht in both cases, and Justice Brennan's dissentimg opinion in Thibodoux is taken, almost verbatin, from his majority opinion in Allegheny. The only plausible attempt to rationalize the two cases is found in the characterization of the state law in Thibodaux, but not in Allegheny, as "unsettled." Crawford v. Courtney, 451 F.2d 489, 492 (4th Cir. 1971); accord, Mayor and City Council v. National Dairy Prods. Corp., 193 F. Supp. 556, 557 (D. Md. 1961). Most commentators have come to regard attempts to reconcile these decisions as futile, e.g., 17 C. WRIGHT, A. Miller \& E. COOPER, supra note 87, \& 4241, at 440; Pell, Abstention-A Primrose Path by Any Other Name, 1972 DE PAUL L. Rev. 926, 951 n.120, and have been content merely to note their potential departure from conventional Burford doctrine. 
ter Haven ${ }^{190}$ that apart from recognized abstention categories, a federal court must decide -state issues properly before it, however difficult or unsettled those issues may be. Thibodaux indicates that stays rather than outright dismissals may be appropriate in Burford as well as Pullman cases, ${ }^{191}$ that trial judges have a larger ineasure of discretion with respect to abstention than was previously recognized, ${ }^{192}$ and that Burford abstention is not limited to requests for equitable relief. ${ }^{193}$

Justice Brennan, writing for the majority in Colorado River Water Conservation District v. United States, ${ }^{194}$ another land use case, described Burford abstention as follows:

Abstention is also appropriate where there have been presented difficult questions of state law bearing on policy problems of substantial public import whose importance transcends the result in the case then at bar [as, for example, in Thibodaux.] In some cases, however, the state question itself need not be determinative of state policy. It is enough that exercise of federal review of the question . . . would be disruptive of state efforts to establish a coherent policy with respect to a matter of substantial public concern [as, for example, in Burford.] ${ }^{195}$

Even this statement is far froin precise. It appears to allow federal courts considerable discretion in deciding when to apply the doctrine. Thus, generalizations about Burford abstention are dangerous. In spite of Justice Brennan's generous characterization of Burford abstention in Colorado River, that opinion also suggests that abstention " is an ex-

190. 320 U.S. 228 (1943). See text accompanying note 330 infra. The literal wording of the Meredith opinion would appear to constrict or nullify the operation of the Burford doctrine, wherein federal courts defer to state court expertise or sensitivity in areas where state law is unclear and the issues are locally sensitive. The Meredith opinion should be read as an attempt to depict abstention as a narrow exception to a general rule rather than as merely treating it as an exception to a rule. In the context of Thibodaux, however, Meredith says that the difficulty of the state law question should not be a basis for abstention if unaccompanied by any other consideration.

191. 360 U.S. at 30. The "stay" disposition may be further evidence that Thibodaux represents not a Burford result but a sui generis exception to Meredith. $C f$. Kaiser Steel Corp. v. W.S. Ranch Co., 391 U.S. 593 (1968) (per curian1) (staying a diversity suit where the issue-water rights-was of vital conceru to the state). The American Law Institute has proposed that the district court retain jurisdiction in all abstention cases with the stay being vacated only if the state proceeding is abortive. AMERICAN LAw INSTITUTE, STUDY OF THE Division OF JURISDiction Between State and Federal Courts \& 1371(d) (Tent. Draft No. 6, 1969). See also Kartell v. Blue Shield, 592 F.2d 1191, 1195 (1st Cir. 1979) (Thibodaux and Kaiser Steel require a stay disposition in Burford cases). Insofar as Thibodaux involved no issues of federal law, it was an unusual Burford case, if it was one at all.

192. 360 U.S. at 30; Comment, Abstention Under Delaney: A Current Appraisal, 49 TEX. L. Rev. 247, 253-54 (1971).

193. 360 U.S. at 28; accord, Willianus v. Hot Shoppes, Inc., 293 F.2d 835, $841-42$ (D.C. Cir. 1961) (en banc), cert. denied, 370 U.S. 925 (1962).

194. 424 U.S. 800 (1976).

195. Id. at 814 (dictum); accord, Kent Island Joint Venture v. Smith, 452 F. Supp. 455, 461 (D. Md. 1978). 
traordinary and narrow exception" "196 to the district court's general duty to decide cases properly before it.

\section{B. The Interplay of Burford and Pullman}

In the last decade, it became increasingly apparent that Burford's underlying inessage of federal noninterference in state and local policies that do not impinge on fundamental personal rights ${ }^{197}$ had great appeal for many lower courts. However, the impetus for this movement has not emanated from the Supreine Court. The inost influential recent formulation of Burford abstention occurred in a case not bottoined on a Burford analysis. ${ }^{198}$ Nevertheless, the recent cases suggest that there are categories of federal cases that, although they do not imvolve a Pullman problem, a demand for equitable relief, or even a concurrent civil or criminal state proceeding, should nonetheless be excluded from federal jurisdiction because of explicit federalism and/or implicit docket concerns. ${ }^{199}$

Although the Burford and Pullman abstention doctrines lave been treated as having distmct rationales and consequences, they tend to merge in application. Although not all Pullman cases are Burford cases, ${ }^{200}$ virtually all nondiversity Burford cases $^{201}$ are also potentially Pullman cases because they imvolve issues of state law that are interwoven, often inextricably, imto the federal claim. Recognition of the Burford component is critical in such cases, simce Burford abstention results in disimissal, rather than deferral as under Pullman. ${ }^{202}$ Unfortu-

196. 424 U.S. at 813 (citing County of Allegheny v. Frank Mashuda Co., 360 U.S. 185, 188-89 (1959)).

197. The limitation of Burford abstention to nonpersonal liberty claims is not explicit in the cases, but its presence is perceptible. Compare Zablocki v. Redhail, 434 U.S. 374, 379-80 \& n.5 (1978) (constitutionality of a statute placing restrictions on marriage) ("of course, no doctrine [requires] abstention merely because resolution of a federal question may result in the overturning of a state policy"), with Santa Fe Land Improvement Co. v. City of Cliula Vista, 71 F.R.D. 573, 576 (S.D. Cal. 1976) (zoning case) (court concerned over consequences of overturning state policy), modified, 596 F.2d 838 (9th Cir. 1979). In Pullman cases, such a distinction has been frequently suggested. See note 158 supra.

198. That reformulation occurred in Colorado River Water Conserv. Dist. v. United States, 424 U.S. 800, 814-15 (1976) (dictum).

199. The Supreme Court has repeatedly disapproved dismissal or remand orders based on grounds of the lower courts' heavy docket. See, e.g., Thermtron Prods., Inc. v. Hermansdorfer, 423 U.S. 336, 344-45 (1976). Nevertheless, federal courts are aware of the impact on their dockets caused by "our federalism." See, e.g., Muskegon Theaters, Inc. v. City of Muskegon, 507 F.2d 199, 205 (6th Cir. 1974).

200. See, e.g., Isthmus Landowners Ass'n v. Califorma, 601 F.2d 1087, 1090-91 (9th Cir. 1979) (per curiam) (reversing the Burford abstention, but remanding for Pullman abstention); Rancho Palos Verdes Corp. v. City of Laguna Beacl, 547 F.2d 1092, 1096 (9th Cir. 1976) (per curiam) (same).

201. But see Record Head, Inc. v. Olsen, 476 F. Supp. 366, 370 (D.N.D. 1979) (Burford abstention only applicable to diversity actions not involving federal constitutional issues).

202. E.g., Kent Island Joint Venture v. Smith, 452 F. Supp. 455,464 (D. Md. 1978); Stall- 
nately, the Supreme Court has not definitively stated which factors distimguish a Pullman from a Burford case.

Although Burford abstention requires the court to determine the adequacy of existimg state remedies, that imquiry should be quite different than the one in Pullman cases. Burford requires that the state remedy must be "plam, adequate and complete" in the classic equitable sense. It must afford the plamtiff an appropriate state means of vindicatimg his federal constitutional claims. ${ }^{203}$

\section{Problems of Theory: Burford and McNeese}

One troublesome question has been whether there should be an unyielding civil rights exception to Burford abstention. The issue arises because of the interplay of Burford and McNeese v. Board of Education, ${ }^{204}$ the primary authority for the proposition that exhaustion of administrative remedies is not required in section 1983 cases. McNeese should preclude Burford abstention only where the state courts to which the federal court would defer are part of a system of judicial review of the administrative process that $M c N e e s e$ held need not be exhausted. ${ }^{205}$ McNeese could, of course, be read more broadly to transcend the exhaustion of administrative remedies issue and to proscribe Burford abstention in all section 1983 cases; Justice Harlan's dissent in McNeese is based on such an interpretation. But such a reading is neither necessary nor wise. The broader federalism concerns that have

worth v. City of Monroeville, 426 F. Supp. 236, 239-41 (S.D. Ala. 1976). But see Santa Fe Land Improvement Co. v. City of Chula Vista, 596 F.2d 838, 841-42 (9th Cir. 1979) (district court abused discretion in dismissing where there were both Pullman and Burford factors); Fralin \& Waldron, Inc. v. City of Martinsville, 370 F. Supp. 185, 193 (W.D. Va. 1973) (since case more like Pullman than Burford, jurisdiction stayed), affd, 493 F.2d 481 (4th Cir. 1974). See also Louisiana Power \& Light Co. v. City of Thibodaux, 360 U.S. at 30.

203. See, e.g., Holmes v. New York City Hous. Auth., 398 F.2d 262, 267 n.7 (2d Cir. 1968). However, this does not import a coalescence of Burford and Younger abstention. For Burford purposes, the state remedy need only be available, not pending, although there is an understandable tendency in some Burford cases to focus attention on the adequacy of pending state litigation. See, e.g., Sixth Camden Corp. v. Township of Evesham, 420 F. Supp. 709, 719-20 (D.N.J. 1976). See also Bador v. East Coventry Township, 325 F. Supp. 1102, 1104 (E.D. Pa. 1971) (\$750 filing fee as a prerequisite to administrative rehef rendered the otherwise appropriate remedy imadequate for abstention purposes).

On the other hand, Burford abstention has been invoked where plaintiff allowed a state statute of limitations to lapse. See Allstate Ins. Co. v. Sabbagh, 603 F.2d 228, 234 (1st Cir. 1979).

204. 373 U.S. 668 (1963); see text accoinpanying notes 83-90 supra.

205. Perhaps McNeese does not extend even this far. The Supreme Court in Gibson v. Berryhill, 411 U.S. 564 (1973) (discussed at text accompanying notes 92-94 supra), stated, "The doctrine of exhaustion of administrative remedies should . . . be kept distinct from other equitable doctrines such as [Younger and Pullman] which do require a federal court to defer in appropriate circumstances to state judicial proceedings." Id. at $574 \mathrm{n} .13$ (emphasis in original). But the availability of state judicial proceedings often requires initial resort to state administrative remedies as in Burford or Alabama Public Service. The practical effect of Burford abstention in such cases would be to displace the McNeese "no administrative exhaustion" rule. 
come to dominate Burford abstention are not necessarily nullified by a general "no administrative exhaustion" holding, because the rationale of that holding is bottomed on efficient allocation of judicial resources $^{206}$ and not on the concern for the right of state governinents to pursue their own prograins and policies. ${ }^{207}$ To conclude that McNeese prohibits Burford abstention in section 1983 cases would not be sound given the substantial doubt that now exists as to the viability of even the limited "no administrative exhaustion" holding of McNeese. The lower federal courts have not read McNeese so broadly, especially in land use cases. ${ }^{208}$

\section{Burford and Land Use Cases}

Zoning cases are typically local im flavor, and often imvolve difficult questions of state and municipal law. As such they represent classic examples of a federal potential for needless imterference, and are best left to the coinplex but comprehensive administrative and judicial regulatory systems provided by state law. Frequently the dual elements of (1) difficult state law questions that (2) transcend the case at bar, stressed by Justice Brennan in Colorado River, are present. In zoning cases the "difficulty" criterion of Burford is often indistimguishable from the "lack of clarity" required under Pullman. ${ }^{209}$ Not surprisingly, courts face similar problems in the Burford context as they do in the Pullman context. For example, the courts should recognize the existence of state law issues even if they are not pleaded exphicitly. ${ }^{210}$ If the case involves federal constitutional issues, then Pullman abstention is clearly indicated, and if the policy problems addressed by the difficult questions of state law also transcend the results in the case at bar, then Burford abstention, too, is in order. ${ }^{211}$ Because Burford abstention re-

206. See Comment, supra note 81 , at 540-42.

207. Construction Aggregates Corp. v. Rivera de Vicenty, 573 F.2d 86, 96 (1st Cir. 1978). See also Allstate Ins. Corp. v. Sabbagh, 603 F.2d 228, 233-34 (1st Cir. 1979).

208. Kent lsland Joint Venture v. Sinith, 452 F. Supp. 455 (D. Md. 1978); Rancho Palos Verdes Corp. v. City of Laguna Beach, 390 F. Supp. 1004 (C.D. Cal. 1975), affd, 547 F.2d 1092 (9th Cir. 1976); Fralin \& Waldron, Inc. v. City of Martinsville, 370 F. Supp. 185 (W.D. Va. 1973), aff'd, 493 F.2d 481 (4th Cir. 1974).

209. E.g., Santa Fe Land Improveinent Co. v. City of Chula Vista, 71 F.R.D. 573, 575-76 (S.D. Cal. 1976), modified on other grounds, 596 F.2d 838 (9th Cir. 1979).

210. See Sixth Camden Corp. v. Township of Evesham, 420 F. Supp. 709 (D.N.J. 1976). The court was consistent, if erroneous, in its refusal to perceive the state law/federal law matrix of the case in both the Pullman and Burford contexts. The court observed that "no questions of state law are presented; plaintiff's claims for damages, excepting any possible pendent claiuns, are purely federal constitutional causes of action." Id. at 720. By the court's reasoning, Burford would be applicable only to diversity cases, since the only source of federal jurisdiction over state law issues in nondiversity cases must be via pendent jurisdiction.

211. Some Pullman cases suggest, although others do not, a counterpart through their apparent insistence that the issues involved be "sensitive" ones. See text accoinpanying notes 168-77 
quires this additional factor, courts that do perceive an unclear state law issue may be less prepared to invoke Burford than Pullman abstention.

The Supreine Court has offered little concrete guidance as to what kinds of issues transcend the case at bar. If eininent doinain cases so qualify, as Thibodaux suggests, ${ }^{212}$ then police power regulations alleged to constitute a coinpensable taking should require similar treatment. Holding communities economically liable in such cases creates the potential for imposing substantial unanticipated costs on local government. $^{213}$ Yet despite explicit recognition of this danger, soine courts have either ignored the abstention question ${ }^{214}$ or have rejected the Burford abstention request as inappropriate because the court's resolution of the substantive claim "is not likely to have significant precedential value or upset any particular scheine of regulation."215 One factor that should be relevant is the scope of the controversy: Where a broad or frontal attack is inade on all or part of a regulatory scheme, the likehhood of transcendent consequences is enhanced, especially if injunctive or declaratory relief is sought. ${ }^{216}$

The treatment of Burford claims in recent land use cases, especially zoning cases, evidences the belief that such cases do not belong in federal court. ${ }^{217}$ For example, in Kent Island Joint Venture v. Smith ${ }^{218}$

supra. The "transcendent" requirement for Burford abstention, on the other hand, appears to be of continuing importance. See, e.g., Colorado River Water Couserv. Dist. v. United States, 424 U.S. 800, 814-15 (1976).

Where both forms of abstention are justified, a dismissal, rather than a stay, is called for.

212. See note 281 infra. But see County of Allegheny v. Frank Mashuda Co., 360 U.S. 185, $191-92$ (1959).

213. Rancho Palos Verdes Corp. v. City of Laguna Beach, 547 F.2d 1092, 1095 (9th Cir. 1976).

214. E.g., Sanfilippo v. County of Santa Cruz, 415 F. Supp. 1340 (N.D. Cal. 1976).

215. Barbaccia v. County of Santa Clara, 451 F. Supp. 260, 264 (N.D. Cal. 1978). The court's conclusion contrasts with that in Sanfilippo v. County of Santa Cruz, 415 F. Supp. 1340 (N.D. Cal. 1976), that "monetary damages are not judicially favored in land regulation cases . . . [b]ecause court-ordered acquisition is likely to be extremely burdensome for the community, and because the burden on the plaintiff can be remedied by removal of the offending land-use restriction ...."Id. at 1343 n.1. See also Rancho Palos Verdes Corp. v. City of Laguna Beach, 547 F.2d 1092 (9th Cir. 1976) (issue of substantial unanticipated costs relevant in a Pullman, but not in a Burford, context, apparently because court views Burford abstention as being limited to the specialized court review situation of Alabama Public Service).

216. See, e.g., Weiss v. Willow Tree Civic Ass'n, 467 F. Supp. 803, 808 n.10 (S.D.N.Y. 1979). But see Holmes v. New York City Hous. Auth., 398 F.2d 262, 267 n.6 (2d Cir. 1968) (as-apphed challenges are better candidates for Burford abstention). The Supreme Court in Steffel v. Thompson, 415 U.S. 452 (1974), recognized that the facial attack has greater potential for disruption of state pohicies in the context of granting declaratory or injunctive relief. Id. at $474 ; c f$. Moore v. Sims, 442 U.S. 415, 427 (1979) (Younger abstention) ("breadth of a challenge to a complex state statutory scheme has traditionally militated in favor of abstention, not against it") (emphasis in origimal).

217. See Studen v. Beebe, 588 F.2d 560, 566 (6th Cir. 1978); Hill v. City of El Paso, 437 F.2d 352, 357 (5th Cir. 1971); Stallworth v. City of Monroeville, 426 F. Supp. 236, 239-40 (S.D. Ala. 
the plaintiff land developer, alleging improper interference with its developinent plans for a residential subdivision, requested injunctive, declaratory, and compensatory relief under sections 1983 and 1985(3), asserting section 1331 and section 1343 jurisdiction. Although the Maryland and federal constitutions posed a Pullman problem, the opinion did not discuss the troublesome mirroring issue. ${ }^{219}$ Nor did the court stress the difficulty of the state law questions or their transcendent nature. Instead, the opinion dwelled on two points. First, it noted that whether an enactment is a proper exercise of the pohice power is an issue routmely decided by state courts. Second, in local land use disputes, federal courts should defer to the state administrative and judicial procedures on federalism grounds, im order to avoid " 'unseemly conflict between two sovereignties [and] the unnecessary impairment of state functions." "220 This sweeping reasoning would justify excluding nost zoning cases not involving first amendment, equal protection, or due process claims from the federal courts.

In generalizing about Burford's application to land use litigation, doctrinal analysis is unsatisfactory because the cases considering Burford abstention are simply not reconcilable. Nevertheless, the dominant pattern in land use cases invoking Burford abstention is (1) the existence of a well-established and effective state procedure for resolving such controversies, usually involving both administrative and judicial review, and (2) a request for federal judicial relief that will interdict such procedures and restram the exercise of authority vested in state officers. ${ }^{221}$ This pattern is consistent with the rationales of $\mathrm{Ala}$ bama Public Service and Thibodaux, and should apply to most zonimg cases. Such an approach has considerable appeal, especially if it is rigidly applied only im property cases rather than personal liberty or racial discrimination suits. Most land use regulatory schemes incorporate elaborate administrative and judicial appeal procedures, and state courts have long been accustomed to handling both constitutional and nonconstitutional issues in this context. Indeed, state courts may be more sympathetic to the substantive merits of challenges premised on

1976); Dells, Inc. v. Mundt, 400 F. Supp. 1293, 1298 (S.D.N.Y. 1975). See also Eastlake v. Forest City Enterprises, 426 U.S. 668, 677 (1976) (suggesting that plaintiff could challenge a referendum result in state court, where plaintiff might have state remedies in addition to whatever relief might be due under the fourteenth amendment).

218. 452 F. Supp. 455 (D. MC. 1978).

219. See text accompanying notes $135-55$ supra.

220. 452 F. Supp. at 463 (quoting Martin v. Creasy, 360 U.S. 219, 224 (I959)).

221. See, e.g., Forest Hills Util. Co. v. City of Heath, 539 F.2d 592, 594-96 (6th Cir. 1976); Hill v. City of El Paso, 437 F.2d 352, 356-57 (5th Cir. 1971); Kent Island Joint Venture v. Smith, 452 F. Supp. 455, 463-64 (D. Md. 1978); Stallworth v. City of Monroeville, 426 F. Supp. 236, 23940 (S.D. Ala. 1976). 
economic injury than are the federal courts. ${ }^{222}$ As a practical inatter, federal courts are not indispensable primary vindicators of federal constitutional rights in zoning cases, at least in cases where there is no valid fear of local prejudice against outsiders or coinplainers.

Besides a general notion that state courts are generally more appropriate forums for overall resolution of zoning controversies, there is also the fear that inaking the federal forum inore readily available, especially for damage renedies, will cause state court zoning litigants to turn en masse to the federal courts. ${ }^{223}$ Federal courts that are unsympathetic to Burford abstention have tended to dismiss such fears as unfounded. For example, im Sixth Camden Corp. v. Township of $E_{\text {vesham }}^{224}$ the court supported its skepticisin about this arguinent by highlighting the $\$ 10,000$ jurisdictional minimuin attaching to section 1331 claims, the fact that state courts can vindicate dainages clamis for federal constitutional violations in zoning cases, and the suggestion that there is sufficient "breathing rooin" between state standards and federal constitutional standards to render the success of a federal claim problematical. ${ }^{225}$ Today, however, only the court's third arguinent supports the conclusion that "damage awards against inunicipalities [are unlikely to] becoine frequent postscripts to zoning litigation."226 Property claims have been cognizable under section 1343 after Lynch v. Household Finance Corp. ${ }^{227}$ in 1972, and municipalities became "persons" within the ineaning of section 1983 in $1978,{ }^{228}$ thus allowing plaintiffs to bring section 1983 suits under section 1343 and thereby circumvent the $\$ 10,000$ jurisdictional minimuin. That state courts can vindicate riglits derived froin the federal Constitution does not inean that plaintiffs will afford thein the opportunity to do so. Rather, that opportumity inay coine about only througl vigorous invocation of the abstention principles that the Sixth Camden court failed to apply. ${ }^{229}$

222. Johnson, Constitutional Law and Community Planning, 20 LAW \& ConTEMP. ProB. 199, 200 (1955). Compare Steel Hill Dev., Inc. v. Town of Sanbornton, 335 F. Supp. 947 (D.N.H. 1971) (conservation oriented, six-acre mimimum lot size upheld), with Aronson v. Town of Sharon, 346 Mass. 598, 195 N.E.2d 341 (1964) (two-and-one-half-acre minimum lot size held to be a taking).

223. This must depend either on the strength of the popular perception that federal courts are more receptive than their state counterparts to claims of federal rights, even in cases where the same rights can also be vimdicated under state law, or upon the extent of the fear of local bias and the resulting preference for federal judges and juries per se.

224. 420 F. Supp. 709 (D.N.J. 1976).

225. Id. at 728-29.

226. Id. at 729 .

227. 405 U.S. 538 (1972) (property rights vimdicable under $\$ 1983$ ).

228. Monell v. Department of Social Servs., 436 U.S. 658, 690 (1978).

229. One category of cases where the federal courts have reached results and articulated rationales strikingly similar to that of Burford abstention involves urban renewal. In this area, the courts of appeal, without calling it abstention, have frequently upheld dismissal orders on the premise that the necessary legal determinations are "more appropriate for the state court to make 


\section{IV \\ YOUNGER ABSTENTION}

In Younger v. Harris ${ }^{230}$ the Supreme Court held that, absent extraordinary circumstances where the danger of irreparable harm to plamtiff's federally protected rights is great and immediate, federal courts should not enjom pending state criminal prosecutions. Since that 1971 decision, the Court has broadened the contours of Younger abstention to include many types of civil cases. ${ }^{231}$ Federalism and comity concerns similar to those in Burford nay trigger Younger abstention, but in practice Younger's focus is much different than that of Pullman or Burford. Younger is not concerned at all with whether any state law is unclear or difficult. Rather, its focus is on the pendency of a parallel state proceeding.

\section{A. Younger and Land Use Litigation}

The idea that the federal courts should avoid interference with state judicial activities is not new. Since 1793, the Anti-Injunction Act has barred the use of federal injunctive power "to stay proceedings in any court of a state." 232 However, the Act is subject to several exceptions. ${ }^{233}$ The Act is now codified at 28 U.S.C. $\$ 2283$, and currently states that a federal court "may not grant an injunction to stay proceedings in a State court except as expressly authorized by Act of Congress, or where necessary in aid of its jurisdiction, or to protect or effectuate its judgments."234 In addition to the three exceptions enumerated in the statute, the courts have created a fourth exception "where a person about to be prosecuted in a state court can show that he will, if the proceeding in the state court is not enjoined, suffer irreparable damages."235 Suits brought under section 1983 are an "expressly authorized" exception to the Anti-Injunction Act's ban. ${ }^{236}$ Thus, today the

... ." Green St. Ass'n v. Daley, 373 F.2d 1, 6 (7th Cir.), ccrt. denied, 387 U.S. 932 (1967). See also Tonwal Realtors v. Beame, 406 F. Supp. 363 (S.D.N.Y. 1976) (abstention from adjudication of rent control controversy).

230. 401 U.S. 37 (1971).

231. An excellent historical account of the cases that are the forerunners of Younger is found in Whitten, Federal Declaratory and Injunctive Interference with State Court Proceedings: The Supreme Court and the Limits of Judicial Discretion, 53 N.C.L. REv. 591 (1975). The Younger doctrine is the subject of extensive commentary. See Comment, Limiting the Younger Doctrine: A Critique and Proposal, 67 CALIF. L. Rev. 1318, 1318 n.3, 1319 n.7 (1979) (citing numerous commentaries).

232. Act of Mar. 2, 1793, ch. 22, \& 5, 1 Stat. 335.

233. See Mitchum v. Foster, 407 U.S. 225, 231-38 (1972) (discussing the Act's history).

234. 28 U.S.C. \& $2283(1976)$.

235. Younger v. Harris, 401 U.S. 37, 43 (1971).

236. Mitchum v. Foster, 407 U.S. 225, 243 (1972). The constitutional basis of Younger v. Harris suggests that Mitchum inay have little impact. In most $§ 1983$ suits, it will be necessary to consider whether Younger requires federal court abstention. Id. at 244 (Burger, C.J., concurring). 
Anti-Injunction Act would not bar a section 1983 suit brought to enjoin state proceedings, although it might bar similar suits brought under 28 U.S.C. $\S 1331 .{ }^{237}$

The Younger doctrine is the constitutional counterpart to the AntiInjunction Act. The case that gave its name to the doctrine arose when John Harris was indicted in a California state court for violating the California Criminal Syndicalism Act. Harris went to federal court to enjom the district attorney's prosecution, claiming that the Act on its face violated the first amendment. The district court held the Act to be unconstitutional, and enjomed prosecution of Harris or anyone else for violations of the Act. ${ }^{238}$ The Supreme Court reversed in Younger $v$. Harris. ${ }^{239}$ The Court held that the district court should not have enjomed the pending state criminal proceeding. Its rationale was twofold. First, courts of equity should not exercise their injunctive power unless plaimtiff will suffer irreparable mjury because there is no adequate remedy at law. ${ }^{240}$ Second, the idea of "comity" or "Our Federalism"241 requires that the federal courts be sensitive to avoid "unduly interfer[ing] with the legitimate activities of the States."242 The combined effect of these two principles im this case required that the federal district court abstain because Harris could fully vindicate his constitutional rights $\mathrm{m}$ his defense to the California prosecution.

Land use cases present interesting wrinkles. A land use case that presents Younger problems is likely to present elements of Burford or Pullman abstention too. Most Younger cases are potentially Pullman cases because the validity of the pending state proceeding under state law is not clear. Burford concerns potentially are present, too, especially im zoning cases. Since Younger abstention is nondiscretionary ${ }^{243}$ and results in dismissal rather than a stay, ${ }^{244}$ the principal consequences of identifying the Younger component of a land use case are that it determines how the abstention is made and put into effect. ${ }^{245}$ Of

237. E.g., County of Imperial v. Munoz, 49 U.S.L.W. 4005 (U.S. Dec. 2, 1980) (commerce clause issue).

238. Harris v. Younger, 281 F. Supp. 507, 517 (C.D. Cal. 1968), rev'd, 401 U.S. 37 (1971).

239. 401 U.S. 37 (1971).

240. Douglas v. City of Jeannette, 319 U.S. 157, 163 (1943) (remedy at law to be judged for adequacy is the remedy at law in the state court).

241. 401 U.S. at 44.

242. Id.

243. Colorado River Water Conserv. Dist. v. United States, 424 U.S. 800, 816 n.22 (1976).

244. But see Echols v. Voisine, 472 F. Supp. 796, 798 (E.D. Mich. 1979) (postponeinent pending exhaustion of a readily available state remedy, citing Younger). The Supreine Court itself has never departed from its insistence on dismissal in Younger cases. See, e.g., Colorado River Water Conserv. Dist. v. United States, 424 U.S. 800, 816 (1976); Gibson v. Berryhill, 411 U.S. 564, 577 (1973).

245. One commentator has suggested that the extension of Younger to civil cases has rendered Pullman abstention "obsolete in federal question cases." Comment, The Abstention Doctrine: Is 
course, federal land use litigation rarely calls for pure, classic Younger abstention, since most such litigation is civil, not criminal. More typically, the application of Younger abstention to land use controversies requires consideration of the difficult issues that have evolved from Younger's progeny.

\section{B. The Nature of the Pending State Proceeding}

A key issue in Younger jurisprudence is whether the doctrine applies where the state proceeding is not actually pendimg when the federal complaint is filed. Younger tended to blur the distmction between pending and threatened prosecutions, and imphed a pervasive proscription against federal interference in state criminal proceedings generally. ${ }^{246}$ This expansive view of the doctrine was limited three years later in Steffel $v$. Thompson, ${ }^{247}$ in which Justice Brennan, ${ }^{248}$ writing for the Court, refused to apply Younger to a threatened state prosecution for criminal trespass, because, in the absence of any actual state proceeding, federal jurisdiction would not threaten the state criminal justice system nor would it slight the state courts' ability to vindicate constitutional rights. ${ }^{249}$

Steffel would result in a rule that Younger abstention offers no protection to defendants in a federal suit if they lose the race to the courthouse, ${ }^{250}$ were it not for Hicks $\nu$. Miranda ${ }^{251}$ In Hicks the federal plaintiff was not made a party to the pending state crimimal prosecution against his einployee for showing an obscene film until the day after plaintiff had filed the federal coinplaint. The court held, without extended discussion, that the race to foreclose the application of Younger was not won in such circuinstances until "proceedings of substance on the inerits have taken place in the federal court."252 To hold otherwise

Pullman Dead in Federal Question Cases?, 30 BAYLoR L. REv. 279, 289 (1978). This overstates the case. Many federal question cases that raise Pullman issues do not call for Younger abstention, either because there is no pending state case at all, or no pending state case that meets the adequacy requireineut of Younger, see text accoinpanymg notes 312-25 infra, or because Younger abstention has been waived. See text accompanying note 307 infra.

246. 401 U.S. at 45.

247. 415 U.S. 452 (1974).

248. Justice Brennan im particular has a long history of hostility to Younger principles, and his majority opinions upholding abstentiou often contain dicta from which it is dangerous to generalize.

249. 415 U.S. at $460-62$.

250. Cf. Village of Belle Terre v. Boraas, 416 U.S. $1,3 \mathrm{n.1}$ (1974) (decided one month after Steffel) (Younger abstention not apphicable, because although the village had served plaintiffs an administrative order to discontinue zoning violations within 48 hours, plaintiffs filed suit in federal court before the subsequent filing of a criminal coinplaint, which by state law had to be preceded by the administrative order); id. at 11 \& $n . *$ (Brennan, J., dissenting) (saine).

251. 422 U.S. 332 (1975).

252. Id. at 349 . 
would be to trivialize the principles of Younger..$^{253}$

The content given the phrase "proceedings of substance on the merits" is important for most cases where interlocutory relief may be sought, such as in land use controversies. Is a hearing on a request for interlocutory relief a proceeding of substance on the merits, inasmuch as such relief requires that the trial court assess the probability of success on the merits? Subsequent cases have shed little hight on this issue. In Doran v. Salem Inn, Inc. ${ }^{254}$ the federal trial court had denied an application for a temporary restraining order against enforcement of an ordinance prohibiting topless dancing, altliougli it subsequently granted plaintiff's' request for a preliminary injunction against the ordinance's enforcement. After denial of the temporary restraining order but before issuance of the preliminary injunction, one plaintiff violated the ordinance and was promptly served with a criminal summons. The other plaintiffs did not allow any topless dancing until the court granted the preliminary injunction. Younger applied to the plaintiff being prosecuted in state court because the federal hitigation was then "in an einbryonic stage and no contested matter had been decided."255 Younger did not apply to the other plaintiffs. It is not clear whether "no contested matter" is synonymous with "proceedings of substance on the merits," or whether it is a further gloss on the latter phrase. ${ }^{256}$

Doran suggests that requests for temporary restraining orders are not "proceedings of substance on the merits." Thus, local officials in land use cases may abort the federal action in a broad range of cases involving requests for such relief by promptly initiating a criminal enforceinent proceeding. ${ }^{257}$ But Doran also supports the idea that a federal court may issue a preliminary injunction against threatened state prosecutions. All a plaintiff need be able to do is to allege credibly the threat of irreparable injury. If this is a proceeding of substance on the inerits, then the effect of Hicks is diminished.

\section{Younger, Threatened Prosecutions, and Declaratory Relief}

The extent to which Younger abstention applies when a plaintiff seeks rehef from a threatened prosecution is unclear. Part of the rehef

253. Id. at 350 .

254. 422 U.S. 922 (1975).

255. Id. at 929.

256. See Wilkenson, Anticipatory Vindication of Federal Constitutional Rights, 41 ALB. L. REv. 459, 534 (1977).

257. This would be possible in any case where the land use activities that the federal plaintiff seeks to vindicate have already been commenced prior to initiation of the federal suit. Thus, despite the Court's treatment of the Younger issue in Village of Belle Terre, see note 250 supra, it would seem that after Hicks v. Miranda, the Court should have decided Village of Belle Terre the other way. 
requested in Steffel was a declaratory judgment that Georgia was applying its criminal trespass statute unconstitutionally. The Steffel Court had two inconsistent lines of analysis on which to draw. In the pre-Younger case of Zwickler v. Koota ${ }^{258}$ the Court had held that the rule that federal courts of equity should not interfere with enforcement of criminal laws did not apply to declaratory judgments. But im Samuels v. Mackell, ${ }^{259}$ the Court found that where the state criminal case was pending, declaratory relief would have the same intrusive effect as injunctive relief and thus was within the ambit of the Younger rule.

The Steffel Court revived Zwickler's distinction between injunctions and declaratory relief, at least in the context of a threatened prosecution. The Court concluded that different factors enter into the decision to grant declaratory relief rather than injunctive relief, since Congress intended that the declaratory judgment be available as a less intrusive means than injunctive relief to test the constitutionality of a state criminal statute. ${ }^{260}$ Thus, ordinary equitable requirements of irreparable injury should not apply to such proceedings. ${ }^{261}$ Whether this distinction, which is artificial and standardless, ${ }^{262}$ continues to be generally viable is uncertain. ${ }^{263}$ If, however, it retams vitality and thus provides an alternative to injunctive relief for the federal trial court, the declaratory reinedy would seem particularly appropriate in land use cases. Once the federal court has declared invalid a local regulation or its application to a particular project, injunctive relief may be unneces-

258. 389 U.S. 241 (1967).

259. 401 U.S. 66 (1971).

260. 415 U.S. at $462-73$.

261. Id. at 471-72.

262. Whitten, supra note 231 , at $680-81$.

263. Declaratory relief often implicates the "case or controversy" requirement, U.S. CoNST. art. III. See, e.g., St. Martin's Press, Inc. v. Carey, 605 F.2d 4l, 44-45 (2d Cir. 1979). Compare O'Shea v. Littleton, 414 U.S. 488 (1974) (action by plaintiffs, who claimed that state officials apphed law discriminatorily to civil rights activists, not ripe because court could not assume that plaintiff's would violate valid law), with United States Civil Serv. Comm'n v. National Ass'n of Letter Carriers, 413 U.S. 548 (1973) (action by plaintiffs challenging Hatch Act as facially vague and overbroad, decided on the merits, although no plaintiff actually threatened personally with sanctions).

There is also soine doubt as to the res judicata and stare decisis cffects of a declaratory judgment. Compare Steffel v. Thompson, 415 U.S. 452, 470-71 (1974) (quoting Perez v. Ledesma, 401 U.S. 82, 124-26 (1971) (Brennan, J., concurring)) (res judicata effect of declaratory judgment " is not free from difficulty," "and that noncomplance with it, although " "inappropriate," does not constitute contempt), with Steffel, 415 U.S. at 482 n.3 (Rehnquist, J., concurring) (favorable declaratory judginent may not be sufficient to support subsequent injunction, and may not have stare decisis effect in state court).

Thus, although some commentators have taken the position that subsequent cases have obliterated any distinction between declaratory and injunctive relief, see $17 \mathrm{C}$. WRIGHT, A. MILLER \& E. COOPER, supra note $87, \S 4253$, at $556-57$, it is probably not wise to conclude that the final rites have been administered in view of the fragmentation of the Court on the highly volatile subject of abstention. 
sary. ${ }^{264}$ This follows from the fact that land use regulations are often subject to facial challenges rather than to "as applied" challenges. The Steffel Court expressly left open the question of the propriety of injunctive relief in the threatened prosecution context, especially with respect to past conduct. Thereafter, although the Court in Doran held that Younger principles do not prohibit the issuance of a preliminary injunction in cases where a plaintiff has no other adequate temporary remedies, ${ }^{265}$ the Court might not be equally approving of a permanent injunction where a plaintiff could defend against the state court prosecution on grounds of the res judicata effect of a prior declaratory judgment or preliminary injunction, since such a defense would be an adequate remedy at law.

Wooley v. Maynard ${ }^{266}$ is the remaining primary authority for the proposition that Younger and "Our Federalism" do not completely eviscerate Ex parte Young, ${ }^{267}$ and leave a narrow spectrum of cases where not only federal declaratory relief, but also federal injunctive relief, agaimst state officers is permissible. In Wooley the Court upheld a perinanent imjunction against prosecution of the plaintiffs for obscuring the motto "Live Free or Die" on their New Hampshire license plates. Although plaintiffs had been convicted of past violations, they were not violating the statute when they brought suit. The Court found present the exceptional circumstances that justify injunctive relief. The threat of prosecution was real and imminent rather than resnote and speculative: The plaintiffs had been prosecuted for and convicted of similar violations on three prior occasions and thus were intimidated from conductimg activities requiring use of their car. ${ }^{268}$ If viewed solely as a threatened prosecution case, ${ }^{269}$ Wooley, in conjunction with Steffel and Doran, could be read to restore the Ex parte Young power of federal injunctive rehef and make Younger abstention inapplicable to many cases. But that trio of cases need not be read so broadly that they dispense with the strict equity requirements for injunctive relief or completely undercut the historical notion that mjunctive relief is mappropriate im the area of administration of state criminal laws. Wooley indicates that a less stringent rule involving a balancing test and a di-

264. Indeed, the landmark zoning case of Village of Euclid v. Ambler Realty Co., 272 U.S. 365 (1926), was singled out as a particularly appropriate candidate for declaratory relief in Justice Brennan's concurring opinion in Perez v. Ledesma, 401 U.S. 82, 115 (1971).

265. 422 U.S. at 930.

266. 430 U.S. 705 (1977).

267. 209 U.S. 123 (1908).

268. 430 U.S. at 712.

269. It is coneeptually difficult to reconcile Wooley with the holding of Huffman v. Pursue, Ltd., 420 U.S. 592 (1975), that Younger principles require that a federal court decline jurisdiction if the would-be federal plaintiff has not exhausted the state appellate reinedies from a peuding state civil nuisance proceeding. 
minished emphasis on the adequacy of state remedies will apparently be applied in cases not mvolving pending prosecutions. However, the greater potential of injunctive relief for interference im local affairs will continue to be a factor that the trial court must consider.

\section{The Extension of Younger to Civil Proceedings}

The courts have extended Younger principles to apply to some state civil judicial proceedings. Were it not for this extension, Younger abstention would be relatively unimportant for land use cases. Although land use regulations are often accompanied by criminal sanctions, ${ }^{270}$ typically the pending or threatened state proceedings are civil in nature. Even where the form of the proceeding is criminal, the court may choose to treat the case as essentially civil. ${ }^{271}$

\section{From Criminal to Related Civil Proceedings}

In Huffman v. Pursue, Ltd. ${ }^{272}$ the Supreme Court began the process of extending the "Our Federahism" primciple of Younger into the civil realm. Huffman held that Younger principles extend to a stateinitiated civil nuisance proceeding closely connected to the state's substantive criminal law, because a federal injunction in the civil case would disrupt the interests that underlie those criminal laws. ${ }^{273}$ Subsequent decisions have extended this approach. In Juidice v. Vail, ${ }^{274}$ one of the parties to purely private civil litigation sought a federal imjunction against the use of a statutory contempt procedure arising out of the private litigation. A three-judge court held that the nature of the hitigation precluded Younger abstention. ${ }^{275}$ The Supreine Court reversed, holding that the state's interest in its contemipt process was an important one entitled to as inuch freedoin from unnecessary federal interfer-

270. See 4 R. ANDERSON, supra note 86 , at $\$ 29.01$.

271. See, e.g., Boraas v. Village of Belle Terre, 367 F. Supp. 136, 140 (E.D.N.Y. 1972), rev'd on other grounds, 476 F.2d 806 (2d Cir. 1973), rev'd, 416 U.S. 1 (1974).

272. 420 U.S. 592 (1975). Similarly, in Moore v. Sims, 442 U.S. 415 (1979), the Court applied Younger to a state civil proceeding over objections that there is no rule "that every pending proceeding between a state and a federal plaintiff justifies abstention unless one of the exceptions to Younger applies. . . ." Id. at 435-36 (Stevens, J., dissenting). Here the object of the federal suit was a Texas law that state officials liad applied against the plaintiff to obtain custody of the plaintiff's children because of child abuse. The inajority likened the case to Huffman, where the proceeding was closely related to criminal statutes. Id. at 423 . Furthermore, that the federal suit was a broad attack on the constitutionality of an entire statutory scheme was not a negative factor in the decision to apply Younger abstention. Sweeping challonges to state statutes inake abstcntion inore, rather than less, appropriate since such challenges usually implicate Pullman concerns also, and often raise serious questions as to the existence of a case or controversy. Id. at 427-29.

273. 420 U.S. at $604-05$.

274. 430 U.S. 327 (1977).

275. Vail v. Quinlan, 406 F. Supp. 951,958 (S.D.N.Y. 1976). 
ence as the state's interest in vindicating its criminal laws. ${ }^{276}$ Subsequently, in Trainor $v$. Hernandez, ${ }^{277}$ federal plaintiffs challenged the constitutionality of the attachment procedures utilized by the state in connection with its suit in state court to recover welfare payinents fraudulently received. A three-judge court held that Younger did not apply, because it was only "happenstance" that the state was a party to the federal suit, since the real object of that suit was a declaration of unconstitutionality of garnishment procedures available to any litigant. ${ }^{278}$ The Supreine Court reversed, holding that the coincidence was dispositive, since the state brought the suit to vindicate important state policies. ${ }^{279}$

Analysis of these cases suggests the following generalizations on the apphication of Younger abstention to pending civil land use hitigation. Two types of civil cases clearly qualify for its application. The first type includes pending state cases that state or local government officials imitiate to vindicate important state interests. ${ }^{280}$ The second consists of cases where the requested federal injunctive relief would interdict important state judicial processes. ${ }^{281}$

The most significant type of land use case not clearly withm the ainbit of Younger abstention, but which nevertheless presents important Younger concerns, occurs where the federal plaintiff initiates a challenge to land use regulations in state court before resorting to the federal forum. In the cases in which the Supreine Court has applied Younger in a civil context, the state had imitiated the pending civil proceedings. ${ }^{282}$ Solne lower courts have seen the character of the state as

276. 430 U.S. at 334-37.

277. 431 U.S. 434 (1977).

278. Hernandez v. Danaher, 405 F. Supp. 757, 760 (N.D. Ill. 1975).

279. 431 U.S. at $443-44$.

280. Huffman v. Pursue, Ltd., 420 U.S. 592 (1975), and Trainor v. Hernandez, 431 U.S. 434 (1977), illustrate this category. None of the Supreme Court civil-Younger cases have yet involved pending suits initiated by local officials to vindicate purely local or municipal interests.

For illustrative land use cases, see Ahrensfeld v. Stephens, 528 F.2d 193 (7th Cir. 1975) (mixed Younger-Pullman case); Salvati v. Dale, 364 F. Supp. 691 (W.D. Pa. 1973) (mixed YoungerPullman case). These cases do not distinguish between state officials vindicating state interests and local officials vindicating local imterests pursuant to state law. Since in a land use setting the vehicle for implementing state land use policies is through delegations of authority to local inunicipahties, it would seem unlikely that the Court will make the application of Younger to such cases turn on a local/state dichotomy.

281. This type of case could arise in a dispute in which the state defendant is only a nominal defendant. A typical example in a land use setting would be a mandamus-type proceeding brought by a landowner to compel enforcement by local officials of a zoning regulation against an adjoining landowner.

282. None of the cases refer to the necessity of the state being a plaintiff. The language is always that the state must be a party. See, e.g., Trainor v. Hernandez, 431 U.S. at 449 (Blackmun, J., concurring). The private plaintiff who brings a state suit challenging the validity of state pohcies and then decides to switch to the federal forum should expect to find at least three of the 
state plaintiff as critical and have refused to abstain where the state was a defendant in the pending state suit. ${ }^{283}$ Although the fact that the state initiated the state court proceedings may highlight the importance of the state's interest in the pending hitigation, equally important state interests may be at stake where a private plaintiff initiates the state suit. This is especially so in the land use context, since governmental officials can only bring suit if the landowner violates the regulation rather than first testing its validity. ${ }^{284}$

\section{Younger and Pending Administrative Proceedings}

A related but conceptually distinct question is whether Younger should encompass purely administrative proceedings pending when the federal suit is initiated. The interests of federalisin and comity that would be served by requiring administrative exhaustion are strikingly similar to those invoked by the Court in applying the abstention doctrines to judicial proceedings. ${ }^{285}$ Ohio Bureau of Employment Services v. Hodory ${ }^{286}$ suggests the possibility that Younger will be extended to such proceedings, but does not resolve the issue. There plaintiff had filed a claun for unemployment benefits, which the defendant had denied. While his request for reconsideration was pending before an administrative board of review, plaintiff filed a federal suit seeking declaratory and injunctive relief. Defendant did not argue that the existence of pending administrative remedies called for the application of Younger principles like the pending civil judicial proceedings did in Huffman, instead arguing that plaintiff must exhaust both pending ad-

Justices decidedly sympathetic to upholding a Younger abstention claim. In the related context of exhaustion of state remedies, Justice Rehnquist, joined by the Chief Justice and Justice Blackmun, dissented from the denial of certiorari in City of Columbus v. Leonard, noting:

Here, the state proceedings were imitiated by respondents rather than by the State. But this only strengthens the rationale for requiring respondents to exhaust their state appellate remedies. Respondents invoked the resources of the State to vindicate what they believed to have been illegal dismissals. Having lost the first round of this contest, they should not be allowed to abandon it and transfer the contest to another arena. As in Huffman, such belated forum shifting is "highly duplicative" and "a direct aspersion on the capabilities and good faith of state appellate courts."

443 U.S. 905,909 (1979) (Inem.) (Rehnquist, J., dissenting).

283. See, e.g., New Jersey Educ. Ass'n v. Burke, 579 F.2d 764 (3d Cir.), cert. denied, 439 U.S. 894 (1978).

284. A major unresolved issue is whether Younger abstention is required where a federal court is requested to interfere with state court litigation between private parties. Although Juidice points the way for expansion of the doctrine to this situation, the circuits are not in agreenent on this point. Compare Lamb Enterprises, Inc. v. Kiroff, 549 F.2d 1052, 1056-58 (6th Cir.), cert. denied, 431 U.S. 968 (1977) (if parties have adequate remedy in the state courts for the constitutional claims, then federal courts should not enjoin state civil action), with Johnson v. Kelly, 583 F.2d 1242, 1249 (3d Cir. 1978) (Younger should not extend to state proceedings not initiated by the state unless the state action is a civil contempt proceeding).

285. Moore v. City of E. Cleveland, 431 U.S. 494, 530 (1977) (Burger, C.J., dissenting).

286. 431 U.S. 471 (1977). 
ministrative remedies and judicial appellate remedies. ${ }^{287}$ The Court $\mathrm{m}$ dicated that the holding in Gibson v. Berryhill ${ }^{288}$ that plaintiff need not exhaust administrative remedies was not dispositive. ${ }^{289}$ Gibson did not involve a pending administrative proceeding and in any event presented a situation where the administrative process was arguably futile because of the "bias" and "incompetence" of the administrative tribunal.

Whether the principles of "they who invoke must exhaust" will be extended to administrative remedies remams to be seen. Three Justices have unequivocally embraced the principle that Younger should be so extended, arguing that Younger abstention is particularly appropriate if the state proceedings were origmally initiated by the forum-jumping federal plaimtiff. ${ }^{290}$ Alternatively, the court may obviate any necessity for "Youngerizing" the administrative remedies area by limiting the holding of Gibson v. Berryhill to its facts and requiring administrative exhaustion in section 1983 cases except where the administrative process is biased or incompetent to adjudicate the issues. ${ }^{291}$

\section{E. Younger, Federalism, and Structural Relief}

One far-reaching extension of Younger may affect land use hitigation. In Rizzo v. Goode 292 the Supreme Court held that Younger's federahism principles counsel agamst system-wide rehef agamst state or local officials who have deprived a plaintiff or a class of plaintiffs of federal constitutional rights. In Rizzo defendants were the Philadelphia mayor, city manager, police chief, and other supervisory officials. The district court ordered them to subinit a comprehensive plan for the correction of systemic police misconduct infringing federal constitutional rights. The Supreme Court concluded that the case was not an article III case or controversy, ${ }^{293}$ and then rejected the theory that a section 1983 action could hold local officials accountable for their failure to take affirmative steps to prevent incidents of misconduct for which they were not directly responsible. ${ }^{294}$ Furthennore, the Court

287. Id. at $477 \&$ n.6.

288. 411 U.S. 564 (1973) (discussed at text accompanying notes 92-93 supra).

289. Gibson presented a situation where the administrative process was futile because of the "bias" and "incompetence" of the administrative tribunal. 431 U.S. at 478 n.8.

290. City of Columbus v. Leonard, 443 U.S. 905 (1979) (mem.) (Rehnquist, J., dissenting). See also Moore v. City of E. Cleveland, 431 U.S. 494, $511-12$ (1977) (Brennan, J., concurring) (no requirement of administrative exhaustion, but noting the inprobability that a variance from the zoning ordinance would lave been granted, and that a fundamental right was involved); Holy Spirit Ass'n v. Town of New Castle, 480 F. Supp. 1212 (S.D.N.Y. 1979).

291. Ohio Bureau of Employment Servs. v. Hodory, 431 U.S. at 478 n.8.

292. 423 U.S. 362 (1976).

293. Id. at 371-73.

294. Id. at 373-77. 
noted that the considerations of federalisin reflected in Doran and Huffman are directly implicated when a plaintiff requests a federal court to issue systein-wide structural injunctions affecting the internal affairs of an executive branch or agency of a state or local government. ${ }^{295}$ Only exceptional circumstances, not present in Rizzo, could justify such intervention. Whether Rizzo imports the birth of a branch of Younger abstention applicable whenever plaintiff seeks a federal injunction affecting the internal administration of a state official's office is unclear. $^{296}$ The Court has subsequently taken no further steps in this direction. ${ }^{297}$

The unost telling criticism of Rizzo is that it lacks the bright line of Younger for determining when the federahism concern becomes paramount, ${ }^{298}$ although the other extensions of Younger have already made this line less distinct than it was when Younger was limited to pending state criminal proceedings. The Rizzo vein of Younger will require considerable fleshing out before it becomes a ineaningful guide to the courts. In its present ainorphous state it is potentially hinitless in its application. In fact, as applied in Rizzo, the analysis would appear to suggest a form of Burford abstention rather than Younger abstention, the reacli of whicl has otherwise been restrained, however loosely, by the pendency requireinent.

Actually, in the land use area, concern about the reach of RizzoYounger abstention tnay be largely unnecessary, although land use litigation witl the potential for raising similar issues is not without precedent. Warth v. Seldin ${ }^{299}$ and Southern Burlington County NAACP v. Township of Mt. Laurel ${ }^{300}$ are two famous examples. Tlie plaintiffs in botll cases clanned to represent classes of ethinc and economic ininorities unconstitutionally deprived of housmg in local mumicipahities by systemic abuse of the police power, and requested that the court mandate, and then supervise, system-wide reform. In $M t$. Laurel a spectacular victory for plaintiffs fully vindicated their decision to use a state court forum. They prevailed on both standing and substantive law, although the New Jersey Supreme Court inodified the trial court's sweeping inandate to permit greater local autonomy with respect to the

295. Id. at 379-80.

296. For the argument that it does, see Weinberg, supra note 12 , at 1215.

297. The courts of appeal have indicated that federal courts should be more hesitant to grant injunctive relief against state or local administrative activity as the requested relief becomes more sweeping and/or affirmative in nature. Lyons v. City of Los Angeles, 615 F.2d 1243, 1247 (9th Cir. 1980) (dictum), appeal pending; Metropohtan Hous. Dev. Corp. v. Village of Arlington Heights, 558 F.2d 1283, 1293 (7th Cir. 1977) (dictum), cert. denied, 434 U.S. 1025 (1978).

298. Weimberg, supra note 12 , at 1223 .

299. 422 U.S. 490 (1975).

300. 67 N.J. 151, 336 A.2d 713 (1975). 
contours of an appropriate remedy. ${ }^{301}$ In Warth, however, plaintiffs failed even to establish standing to bring suit, and so never reached a determination on the merits. Warth suggests that in the land use setting, the federal courts might never reach the Rizzo question. Moreover, Rizzo-Younger considerations probably would not be of much concern in any land use case sufficiently concrete to allow the exercise of federal jurisdiction, since sucli a case will also permit the fashioning of a minimally imtrusive remedy.

However, there las been some suggestion that Rizzo concerns were present in Village of Arlington Heights v. Metropolitan Housing Development Corp. ${ }^{302}$ The Supreme Court held that the plaintiffs' challenge to the Village's failure to rezone an area to permit the construction of a low- and moderate-imcome housing project satisfied the test for standing articulated in Warth. ${ }^{303}$ The Court held that a failure to estabhish discriminatory intent was fatal to the plaintiffs' equal protection claim and remanded the case for consideration of alleged violations of the Fair Housing Act. ${ }^{304}$ The court of appeals on reinand concluded that the nature of the relief requested was critical:

The courts ought to be more reluctant to grant rehef when the plamtiff seeks to compel the defendant to construct integrated housing or take affirmative steps to ensure that integrated housing is built than when the plaintiff is attempting to build integrated housing on his own land and merely seeks to enjoin the defendant from interfering with that construction. To require a defendant to appropriate money, utilize his land for a particular purpose, or take other affirmative steps toward integrated housing is a massive judicial intrusion on private autonomy. ${ }^{305}$

Such expressions of concern over the desirability of limiting the scope of federal judicial intervention are similar to those expressed in Rizzo.

301. The New Jersey Supreme Court has recently backed away from the imprimatur it gave to judicially mandated affirmative action remedies in Mt. Laurel, which required that Mt. Laurel adopt a zoning ordinance that affirmatively afforded an opportunity for low- and inoderate-imcome housing to be built within the jurisdiction. 67 N.J. at 174, 336 A.2d at 724 . In Oakwood v. Township of Madison, 72 N.J. 481, 512, 371 A.2d 1192, 1207 (1977), the remedy was far unore modest. The court required the township to "adjust its zoning regulations so as to render possible and feasible the 'least cost' housing" that private indnstry would undertake. Such "least cost" housing might still have cost too much for nost low- and noderate-income consumers, and, in any event, private industry was free to decline the invitation that the adjusted zoning extended.

302. 429 U.S. 252 (1977).

303. Id. at 260-64. In Warth the court required prospective residents of proposed housing projects to demonstrate in a concrete way that their financial resources would permit then to acquire the proposed housing. 422 U.S. at 502-05. In Arlington Heights this requirement is simiply ignored. This is difficult to reconcile with the theory that the standing rules articulated in Warth refiected a basic decision by the Court against federal jurisdiction in this type of case.

304. 42 U.S.C. $\$ \S 3601-3631$ (1976).

305. 558 F.2d 1283, 1293 (7th Cir. 1977), cert. denied, 434 U.S. 1025 (1978). 


\section{F. The Younger Exceptions}

Generally, if a case calls for Younger abstention, only extraordinary circumstances prevent its apphication. The state may waive the application of Younger on the theory that since the purpose of Younger is to allow the state the " 'opportunity to set its house in order," "306 the Younger concerns are not implicated where the state would like the federal court to do the housekeeping. ${ }^{307}$ If the state chooses to insist on freedom from federal intervention, only in extraordinary situations and upon a "showing of bad faith, harassinent, or any other unusual circumstances that would call for equitable relief" ${ }^{\prime 308}$ may Younger abstention be avoided. The kind of exceptional circumstances that would qualify are virtually nonexistent. ${ }^{309}$ Except by way of Younger's reference to the circumstances of Dombrowski $v$. Pfister, ${ }^{310}$ a first amendment case, the Court has never found the bad faith or harassment that would qualify. For example, the mere fact that local officials are zealous in their enforcement of state law that they mistakenly believe to be vahid and constitutional is insufficient to establish the requisite bad faith prosecution or harassment. ${ }^{311}$

One approach that may succeed in preventing Younger's application is to challenge the adequacy of the pending state proceeding to vindicate the federal plaintiff's constitutional claims. A federal court's interference with inadequate state proceedings is not such a sufficient affront to Younger's concerns of comity and federalism as to rcquire the court to withhold relief. In the classic Younger setting of a pending criminal prosecution, the adequacy requirement poses few difficulties, even if plaintiff seeks prospective as well as retrospective relief. Once the constitutional defense is successfully asserted in the pending state prosecution, it is presumed that state officials will not thereafter repeat their prosecutorial efforts as to future conduct. ${ }^{312}$

306. Ohio Bureau of Employment Servs. v. Hodory, 431 U.S. 471, $479-80$ (1977).

307. See id. at 480 . Although some courts have raised the Younger abstention issue sua sponte, see, e.g., Zablocki v. Redhail, 434 U.S. 374, 379 n.5 (1978); Sosna v. lowa, 419 U.S. 393, 396 n.3 (1975), such a practice may be imconsistent with the waiver rule. See 17 C. WRIGHT, A. MILLER \& E. COOPER, supra note $87, \S 4252$, at 547-48.

308. Younger v. Harris, 401 U.S. at 54.

309. 17 C. Wriahr, A. Miller \& E. Cooper, supra note 87, \& 4255, at 583-86; Fiss, Dombrosski, 86 YALE L.J. 1103, 1115 (1977). But see Wooley v. Maynard, 430 U.S. 705,712 (1977); note 269 supra.

310. 380 U.S. 479 (1965).

311. Hicks v. Miranda, 422 U.S. 332, 350-51 (1975). Lower courts that have considered a claim of the requisite extraordinary circumstances have done so in the context of a motion for preliminary injunction, a fact that tends to confuse the issue, since such motions are often tried by affidavit. See, e.g., Rogers v. City of Kingston, 446 F. Supp. 229, 231 (S.D.N.Y. 1978).

312. If not, then the use of federal declaratory relief will be equally ineffective if Justice Brennan is correct in his insistence that declaratory judgments do not have the same binding effect as injunctions do. See note 263 supra. However, the broader question this poses-the wisdom of 
With the increasing application of Younger principles to pending civil cases the question of adequacy is not so simple. In state criminal prosecutions the constitutional defense is rarely unavailable. But constitutional defenses sometimes cannot be raised in administrative proceedings. The Supreme Court did not apply Younger to Gibson $v$. Berryhill $^{13}$ on the ground that the administrative proceedings were before a biased body and therefore did not afford "the opportunity to raise and have timely decided by a competent state tribunal the federal issues involved."314 When, in Huffman v. Pursue, Ltd., ${ }^{315}$ the Court did apply Younger to a type of civil case, the concern about adequacy of the state remedy again surfaced because the federal plaintiff had not appealed from the trial court's determination that its actions constituted a nuisance. ${ }^{316}$ Although the Court in Huffman discussed the problem of the unexhausted appellate remedy in terms of whether the state proceeding contimues to be pending for Younger purposes, it would seem equally appropriate to regard the availability of such appellate remedies as an aspect of adequacy. The rule that sliould einerge from Huffman is fairly straightforward: Once an adequate state judicial proceeding is pending, the federal plaintiff nay not destroy its adequacy by failing to pursue it. ${ }^{317}$

Younger in terms of its practical effcctiveness in protecting constitutional rights and assuring freedom from harassmeut-is at the core of most critics' complaimts about the Younger doctrine. See, eg., Redish, The Doctrine of Youuger v. Harris: Deference in Search of a Rationale, 63 CORNELL

L. REV. 463 (1978).

313. 411 U.S. 564 (1973) (discussed at text accompanying notes 92-93 supra).

314. Id. at 577 .

315. 420 U.S. 592 (1975).

316. The federal defendants did not plead res judicata. Id. at 607 n.19. The exhaustion rule announced in Huffman should prevent the res judicata issue from arising except in cases where the state remedy is otherwise inadequate.

317. The apphicability of the Huffman rule to pending state civil proceedings initiated by the federal plamtiff is questionable. In Isthmus Landowners Ass'n v. California, 601 F.2d 1087 (9th Cir. 1979) (per curiam), the plaintiff filed substantially similar complaints in both state and federal courts charging the California Coastal Zone Conservation Commission with violations of state and federal law arising out of its demal of a development permit. The federal district court ordered the action " 'stayed in all respects pending either final determination or plaintiff's dismissal of said state court action.' "Id. at 1089 . Thcreafter, although the plaintiff dismissed the state suit, the fcderal district court dismissed the federal action, apparently on Burford abstention grounds. The Ninth Circuit, which takes a narrow view of Burford abstention, see cases cited note 200 supra, reversed the Burford dismissal, but rcmanded for application of Pullman abstention. Why the court did not consider the case an appropriate candidate for Younger abstention is not clear, since it took judicial notice that the plaintiff had filed a new permit application that was "now the subject of litigation in state courts." 601 F.2d at 1090. Even if sucl an action had not been pending when the federal action was filed, Huffman and Moore v. Sims, 442 U.S. 415 (1979) (discussed at note 272 supra), would suggest that, once commenced, the state judicial proceedings are the appropriate vehicle for vindicating both the plaintiffs state and federal claims. One difference between Isthmus and Hufman and Moore is that in Isthmus the fcderal plaimtiff had control of the state suit. It could seek dismissal if it chose, whereas in Huffman and Moore the federal plaintiff was a state court defendant and only had control over the appellate process and the scope 
In some cases, however, the inadequacy of the state remedy mures in the very nature of the pending proceeding. Trainor $v$. Hernandez ${ }^{318}$ illustrates this scenario. Although the Court declined to rule on whether the state court was an "adequate forum for hitigating the federal claim," 319 Justice Stevens' dissent suggested that the state garnishinent proceeding was defective in two respects. First, motions to quash the attachment could not be predicated on constitutional grounds, and, second, orders denymg such motions were imterlocutory and nonappealable. ${ }^{320}$

This type of adequacy problem may be present in some zoning controversies. Solne state courts have taken the position that constitutional objections to the vahdity of a zoning ordinance or actions taken thereunder are not withm the jurisdiction of a local zoning board of appeals. ${ }^{321}$ In view of the supreinacy clause, however, such a limitation cannot unean that the scope of judicial review is similarly delimited, especially where it involves de novo review. ${ }^{322}$ Furthermore, under

of potential counterclaims. Whether this is a critical difference is doubtful. Certainly the other Younger criteria were inet. The state was a party, the state interests were inportant, and the court of appeals found that the state remedies were adequate. Thus, in the context of judicial remedies, the apphication of the "they who invoke must also exhaust" primciple would seem appropriate. City of Columbus v. Leonard, 443 U.S. 905, 907 (1979) (mein.) (Rehnquist, J., dissenting).

318. 431 U.S. 434 (1977).

319. Id. at 447 n.10.

320. Id. at 467 (Stevens, J., dissenting).

321. Such boards exercise delegated powers that do not include the power to decide the constitutionality of the ordinance. See, e.g., Zelvin v. Zoning Bd. of Appeals, 30 Conn. Supp. 157, 306 A.2d 151 (1973); Monoco Oil Co. v. Town of Pittsford, 59 Misc. 2d 750, 300 N.Y.S.2d 488 (1969). Land use cases will frequently be distinguishable from other cases dealing with the propriety of administrative agencies deciding constitutional questions as to the scope of their own powers. In most other situations, because the very statute that grants the agency its power is also the subject of the constitutional challenge, it would be incongruous if the agency were bound by the legislative pronounceinent on statutory law but could ignore the imphed decision of the legislature on the constitutional question. See Fuchs, Prerequisites to Judicial Review of Administrative Agency Action, 51 IND. L.J. 817, 883-92 (1976). Although this theory has been largely discredited, at least on the basis of federal constitutional law, see Swan, Administrative Adjudication of Constitutional Questions: Confusion in Florida Law and a Dying Misconception in Federal Law, $33 \mathrm{U}$. MIAMI L. REv. 527, 567-90 (1979), it would not appear to be applicable to most land use cases anyway. Typically a zoning board of appeals is created by a state enabling act, while the ordinance which is the subject of the challenge is a local enactment passed by the municipality pursuant to the delegation by the legislature contained in the enabling act. See Southern Pac. Transp. Co. v. Public Util. Comm'n, 18 Cal. 3d 308, 556 P.2d 289, 134 Cal. Rptr. 189 (1976) (adıninistrative agencies have a constitutional duty to consider such challenges); National Land \& Inv. Co. v. Korn, 419 Pa. 504, 215 A.2d 597 (1965).

322. It is doubtful that a court can constitutionally decline to entertain a federal constitutional defense. See, e.g., People v. Max, 70 Colo. 90, 198 P. 146 (1921). Where review is de novo, however, it may plausibly be said that the state proceedings are adequate for Younger, as the grant of de novo review will in all likelihood entail some initial factfinding by the reviewing court and thus place at least part of this function in the hands of a forum capable of hearing constitutional cluallenges. But see note 104 supra. 
Moore v. Sims, ${ }^{323}$ the adequacy of the state proceeding may not be determined solely by the range of issues that the state court ininimally must consider in the suit before it. If the federal constitutional claims can be raised, whether by way of defense, permissive counterclaim, setoff, or recoupment, Moore requires the plaimtiff to try to utilize the pending proceeding to that end, ${ }^{324}$ in inuch the same way that Huffman requires the federal plaintiff to perfect appellate remedies in a Younger setting. ${ }^{325}$ In a zoning appeal, then, Moore would require a landowner who takes a judicial appeal from an unsatisfactory administrative decision to exhaust the potential of the state case to resolve the federal claims by joining, where procedurally possible, that state appeal with a demand on the state court for declaratory or mjunctive relief on constitutional grounds. Even if Moore is taken at its word regarding the exhaustion aspect of the adequacy issue, it does not follow that a landowner who wishes to avoid Younger abstention need forego the opportunity to attempt imitially to resolve the land use problein by local adinimistrative processes. Resort to such avenues of rehef is often desirable and may come to be mandated if the section 1983 "no administrative exhaustion" rule of $M c N e e s e$ is curtailed. Moore may mean that once the administrative remedy is exhausted, the unsuccessful participant may have to choose between pursumg a state judicial appeal from that decision or initiating a suit im federal court.

The Huffman rule is unexceptional, and is hardly a de facto overruling of the Monroe v. Pape ${ }^{326}$ rule that section 1983 suits do not require exhaustion of state judicial remedies. ${ }^{327}$ The Huffman rule only

323. 442 U.S. 415 (1979) (discussed at note 272 supra).

324. Id. at 430 n. 12 .

325. Even before Moore v. Sims, some federal courts applied such a rule in domestic relations litigation. See, e.g., Gras v. Stevens, 415 F. Supp. 1148, 1153 (S.D.N.Y. 1976) (three-judge court); Kahn v. Shainswit, 414 F. Supp. 1064, 1068 (S.D.N.Y. 1976). Even if Moore does not require this, the existence of Pullman issues in the Younger case may produce the same practical result. If the trial court dismisses on both Pullman and Younger grounds and the federal plaimtiff appeals that ruling, he must litigate the pending state court proceeding pending resolution of his appeal with two objectives in inind. He must seek resolution of the state law issues so that if he wins on the Younger issue but not on the Pullman issue, the Pullman issue will be mooted. Second, he nust lay the necessary framework for vindication of all his claims in the state court lest he lose on the Younger issue. The following dilemma may arise. If he foregoes the use of the England procedure which permits the Pullman federal plaintiff to withdraw the federal constitutional issues from the state court's determination, see note 161 supra, on the assumption that he may lose the Younger appeal, he may be barred by res judicata from relitigating the issue in federal court if he wins his federal appeal on the Younger issue. Conversely, if he employs the England procedure and withdraws the federal claim from the state court's determination, he may be barred by res judicata from ever hitigating the claim in state court if he loses the Younger appeal, especially if the state court applies the "could have litigated" test. For an example of this problem, see New Jersey Educ. Ass'n v. Burke, 579 F.2d 764 (3d Cir.), cert. denied, 439 U.S. 894 (1978).

326. 365 U.S. 167 (1961).

327. For the contrary argument, see Soifer \& Macgill, supra note 12, at 1183-85. 
requires that plaintiffs who pursue state judicial remedies contimue them; but there is nothing to prevent these plaintiffs from choosing the federal forum at the outset. Neither does the Moore rule overrule Monroe v. Pape. It only requires that, at the culmination of the administrative process, plamtiff choose between seeking a remedy in state or federal court; and that if he chooses state court, he pursue that route to a conclusion.

\section{$\mathrm{V}$ \\ COLORADO RIVER ABSTENTION-CONTEMPORANEOUS EXERCISE OF CONCURRENT JURISDICTION}

A case that involves neither federal constitutional issues nor state issues with transcendent state policy ramifications might nevertheless require a federal court to abstam, solely to allow a state court to decide unsettled questions of state law. ${ }^{328}$ Meredith $v$. Winter Haven ${ }^{329}$ rejected such an approach, however, at least in the context of a diversity action. The Court's rationale was straightforward: In the absence of some policy to the contrary, diversity jurisdiction requires federal courts to decide all questions of state law, whether uncertain or not. ${ }^{330}$

In Louisiana Power \& Light Co. v. City of Thibodaux ${ }^{331}$ the Court carved out an exception to Meredith for diversity cases implicating uncertain questions of state eminent domain law. There the Court upheld the trial court's grant of a stay until the state court had an opportunity to construe the statute at issue. Thibodaux by itself represents a very limited incursion on the principle that the mere existence of unsettled questions of state law does not, without more, justify any form of abstention. ${ }^{332}$ Judicial departures froin Meredith have been modest, ${ }^{333}$ although occasionally the lower courts have strayed. ${ }^{334}$ More important, it now appears that federal courts may certify to the state courts uncer-

328. See, e.g., Thompson v. Magnolia Petroleum Co., 309 U.S. 478, 483-84 (1940) (dictum).

329. 320 U.S. 228 (1943).

330. Id. at 236.

331. 360 U.S. $25,28-29$ (1959).

332. See 17 C. WRIGHT, A. Miller \& E. CoOPER, supra note 87, 84246 , at 495 . But see Field, supra note 107, at 1152 (arguimg for the application of the Pullman doctrine to nonconstitutional cases, thus making the Thibodaux doctrine the general rule).

333. Subsequent Supreme Court decisions have reaffirmed Meredith's soundness. See Colorado River Water Conserv. Dist. v. Umited States, 424 U.S. 800, 816 (1976); McNeese v. Board of Educ., 373 U.S. 668, 673 n.5 (1963).

334. E.g., United Servs. Life Ins. Co. v. Delaney, 328 F.2d 483 (5th Cir.), cert. denied, 377 U.S. 935 (1964); White v. Husky Oil Co., 266 F. Supp. 239 (D. Mont. 1967); Richey v. Sumoge, 257 F. Supp. 32 (D. Or. 1966); A.F.L. Motors, Inc. v. Chrysler Motors Corp., 183 F. Supp. 56 (E.D. Wis. 1960). Delaney has not been well received. See Currie, The Federal Courts and the American Law Institufe (Part II), 36 U. CHI. L. REV. 268, 313-14 (1969); Shapiro, Abstention and Primary Jurisdiction: Two Chips Off the Same Block?-A Comparative Analysis, 60 CORNELl L. REv. 75, 103-04 (1974); Comment, supra note $19 \dot{2}$. 
tain questions of state law without offending the strictures of Meredith. ${ }^{335}$ Occasionally.courts have relied on Thibodaux in noneminent doinain cases based in part on statutory federal claims, but in inost such cases the reliance was unnecessary because the classic Pullman basis for abstention was present. ${ }^{336}$

\section{A. The Colorado River Doctrine}

However, in Colorado River Water Conservation District v. United States, ${ }^{337}$ the Court abstained in a situation that differed from the Meredith-Thibodaux scenario in that the state case was pending at the time the federal court abstained. Although the Colorado River case featured uncertain state law issues, nore important apparently was the fact that the concurrent state jurisdiction was contemporaneous rather than potential. ${ }^{338}$ Like Thibodaux, Colorado River can be viewed as constituting an exceedingly narrow exception to the general rule that jurisdiction conferred is jurisdiction that must be exercised..$^{339}$ The setting of Colorado River was the concurrent state-federal jurisdiction, created by the McCarran Amendment, ${ }^{340}$ over river water rights disputes. The federal government filed suit in federal court seeking a declaration of its water rights claimed to arise under both state and federal law. Subsequently, the United States was nained as a defendant in a state suit brought under the Colorado Water Right Determination and Administration Act, ${ }^{341}$ which provided for continuous adjudication of water rights within one of seven water drainage divisions. The federal district court then dismissed the proceedings before it.

Justice Brennan's majority opimion found that, although tradi-

335. See Lehman Bros. v. Schein, 416 U.S. 386, 390-91 (1974).

336. See, e.g., Fralin \& Waldron, Inc. v. City of Martinsville, 493 F.2d 481 (4th Cir. 1974). The trial court had exphcitly relied on Pullman and Burford abstention. 370 F. Supp. 185, 189-90 (W.D. Va. 1973).

337. 424 U.S. 800 (1976).

338. Long before Meredith the Supreme Court had held in McClellan v. Carland, 217 U.S. 268,282 (1910), that the mere pendency of an action in a state court is no bar to proceedings concerning the same matter in a federal court. Brillhart v. Excess Ins. Co., 316 U.S. 491 (1942), represented a moderate retreat from this principle, but appeared to be premised on the discretionary nature of diversity-based declaratory judgment proceedings. Soine lower federal courts granted stays on the theory that such a principle is a forn of abstention justified as a matter of discretion in exceptional circumstances even after Meredith. See, e.g., Mottolese v. Kaufman, 176 F.2d 301 (2d Cir. 1949).

339. See, e.g., Comment, Federal Court Stays and Dismissals in Deference to Parallel State Court Proceedings: The Impact of Colorado River, 44 U. CHI. L. REV. 641 (1977).

340. 43 U.S.C. $\$ 666$ (1976). For a good discussion of the historical development of concurrent state-federal jurisdiction over reserved water rights, see Abrams, Reserved Water Rights, Indian Rights and the Narrowing Scope of Federal Jurisdiction: The Colorado River Decision, 30 StaN. L. REV. 1111 (1978).

341. Colo. Rev. Stat. $\$ \$ 37-92-101$ to $37-92-602$ (1973). 
tional abstention doctrines were inapplicable, ${ }^{342}$ the trial court's disposition should neverthelcss be sustained. In order to avoid waste of judicial resources caused by duplicative litigation, ${ }^{343}$ Justice Brennan recognized and gave substance to a fourth category of abstention. The Court found numerous precedents for this category of abstention: (1) cases upholding the primacy of the court first assuming jurisdiction of the res; ${ }^{344}$ (2) cases establishing the federalization of the forum nonconveniens doctrine; ${ }^{345}$ and (3) cases pernmitting a federal court to decline jurisdiction in favor of a pending state proceeding to avoid pieceineal litigation. The third line of cases seems the closest precursor of the Colorado River decision. Thus, in Brillhart v. Excess Insurance Co., ${ }^{346}$ the plaintiff had sought a declaratory judgment to determine its rights under a reinsurance agreeinent. The district court dismissed the suit. Holding that the district court could so dismiss a suit, the Court stated:

[I]t would be uneconomical as well as vexatious for a federal court to proceed in a declaratory judgment suit where another suit is pending in a state court presenting the same issues, not governed by federal law, between the same parties. Gratuitous interference with the orderly and comprehensive disposition of a state court litigation should be avoided.

Where a District Court is presented with a claim such as was made here, it should ascertain whether the questions in controversy between the parties to the federal suit, and which are not foreclosed under the applicable substantive law, can better be settled in the proceeding pending in the state court. This may entail inquiry imto the scope of the pending state court proceeding . . . ${ }^{347}$

The Colorado River Court held that the avoidance of piecemeal adjudication was the primary factor counseling against concurrent federal jurisdiction, coinparing that factor to policies seeking to avoid inconsistent dispositions of the same property caused by concurrent

342. 424 U.S. at 817.

343. Id.

344. Donovan v. City of Dallas, 377 U.S. 408,412 (1964); Princess Lida v. Thompson, 305 U.S. 456, 466 (1939).

Another line of cases, identified by Justice Brennan as representing a different policy, but in fact closely related to these cases, was a series of decisions holding that the order in which the courts obtamed jurisdiction is one determinant of the propriety of retention of jurisdiction. For this proposition, Justice Brennan cited Pacific Live Stock Co. v. Oregon Water Bd., 241 U.S. 440, 447 (1916), where the order of acquiring jurisdiction was not critical, and which inay plausibly be viewed as an exhaustion of administrative remedies case rather than as a concurrent jurisdiction case. See P. Bator, P. Mishkin, D. Shapiro \& H. WechSler, HART \& Wechsler's The FedERAL COURTS AND the FEDERAL SySTEM 983 (2d ed. 1973).

345. Gulf Oil v. Gilbert, 330 U.S. 501 (1947) (holding that a federal court has discretion to invoke the forum non conveniens doctrine without regard to whether the convenient forum will be a federal or state court). In Colorado River the fcderal forum was inconvenient because it was 300 miles froni the appropriate local forum. 424 U.S. at 820.

346. 316 U.S. 491 (1942).

347. Id. at 495 . 
jurisdiction. ${ }^{348}$ Other factors that counseled against exercising jurisdiction were the inconvenience of the federal forum, ${ }^{349}$ the extensive involvement of state water rights, ${ }^{350}$ and the absence of any other proceedings in the district court. ${ }^{351}$

There are two ways for the courts to deal with the problems of judicial administration inherent in contemporaneous concurrent jurisdiction. One would be to enjoin exercise of jurisdiction by the other court. ${ }^{352}$ However, state courts constitutionally cannot enjoin proceedings im federal courts, ${ }^{353}$ and federal courts statutorily cannot enjoin proceedings in state courts. ${ }^{354}$ The second way to treat the problems of contemporaneous concurrent jurisdiction would be by abstention. Thus, federal courts may passively avoid these problems by deferring to their state counterparts. This is the message of Colorado River. It would be entirely consistent with Colorado River to extend this approach beyond the confines of the McCarran Act, although it would be possible to limit Colorado River by emphasizing the McCarran Act's particularized policy of avoiding piecenneal adjudications in water rights disputes. ${ }^{355}$ More broadly formulated atteinpts to confine Colorado River are not convincing. For example, the argument that a state court should not be allowed to accomplish indirectly-by allowing the state plaintiff to proceed vigorously so as to meet the criteria of Colorado River - what it cannot accoinphisl directly-by enjoining the federal court-has soine appeal. However, it depends on the dubious premise that state courts could or would engage in docket manipulation with the idea of defeating federal jurisdiction. Even if this actually oc-

348. 424 U.S. at 819.

349. See note 345 supra.

350. It is a bit puzzling why the allocation of water rights was not treated as a Burford issue in view of the complexity of the allocative scheme and the consequently high probability that a federal court unversed in the scheme would commit a disruptive error. In Kaiser Steel Corp. v. W.S. Ranch Co., 391 U.S. 593 (1968) (per curiam), the Supreme Court had held that the lower federal court should have abstained when presented with a novel issue of the allotment of water rights in an arid region.

351. 424 U.S. at 820 . This factor is suggestive of the "proceedings of substance on the inerits" test of Hicks. See text accompanying notes 252-57 supra.

352. In the interstate setting this solution, although sometimes attempted, poses substantial difficulties. See James v. Grand Trunk W.R.R., 14 III. 2d 356, 372, 152 N.E.2d 858, 867 (1958) (suggesting the "through the looking glass" possibilities of enjoining the enjomer). For further explanation, see Comment, Forum Non Conveniens, Injunctions Against Suit and Full Faith and Credit, 29 U. CHI. L. Rev. 740 (1962); Comment, Full Faith and Credit to Foreign Injunctions, 26 U. CHI. L. Rev. 633, 636 (1959).

353. General Atomic Co. v. Feltner, 434 U.S. 12, 18-19 (1977); Donovan v. City of Dallas, 377 U.S. 408, 413-14 (1964).

354. 28 U.S.C. $\$ 2283$ (1976) (Anti-Injunction Act). None of the statutory exceptions to the Act have yet been construed to vindicate the policies central to the decision in Colorado River.

355. 424 U.S. at 819. See also Northern Cheyenne Tribe v. Tougue River Water Users Ass'n, 484 F. Supp. 31, 36 (D. Mont. 1979) (water rights). 
curred, it is not clear that it would be worse than the two courts otherwise racing to potentially inconsistent judgments. Whether Colorado River marks either the beginning or a reaffirmation of a general policy applicable to diversity jurisdiction remains to be seen. ${ }^{356}$

\section{B. Colorado River and Land Use Litigation}

Colorado River suggests two possibilities in the land use context. First, if it were treated as a vigorous endorsement of the discretionary authority, enunciated in Brillhart, to decline to exercise jurisdiction over duplicative concurrent litigation, it might find sone margmal application im diversity cases not already subject to abstention on Pullman or Burford grounds. Second, and more imteresting, it might be applied to section 1983 cases that are also the subject of ongoing proceedimgs in a state court. The Court has already reached a similar result in some situations through the apphication of Younger abstention to state civil proceedings, or through an expansive application of Pullman or Burford abstention. ${ }^{357}$

Recently, the Court has given some indication of its intention to apply the Colorado River doctrine to cases of exclusive federal jurisdiction, even though the traditional view is that such cases call particularly strongly for the Meredith rule of exercising jurisdiction conferred..$^{358}$ In Will v. Calvert Fire Insurance Co ${ }^{359}$ four Justices endorsed the Colorado River principle where the federal clain also raised an issue implicated in the pending state proceeding, ${ }^{360}$ although the federal plaintiff sought damages rather than declaratory relief ${ }^{361}$ and the federal jurisdiction was exclusive with respect to one aspect of the controversy.

356. The uncertainty of the extent of the Colorado River doctrine is exemplified by that Court's express reservation of the question of whether it would reach the same result if a private litigant were to initiate the federal water suit. 424 U.S. at 820 n.26.

357. See note 177 and accompanying text supra.

358. E.g., Cotler v. Inter-County Orthopaedic Ass'n, 526 F.2d 537, 542 (3d Cir. 1975).

359. 437 U.S. 655, 664 (1978) (Rehnquist, J., joimed by Stewart, White, and Stevens, JJ.).

360. The federal plaintiff, Calvert Fire Insurance Co., was defending agaimst a state suit seeking a declaration as to its status in a reinsurance pool agreement. In the state suit, Calvert lad asserted the unenforceability of the pool agreement under various state and federal laws. It also counterclaimed for damages under each of these laws except Rule 10b-5, promulgated under § 10(b) of the Securities Exchange Act of 1943, 15 U.S.C. \& 78j(b) (1971), which, under that Act, was exclusively cognizable in federal court. On the same day it filed the state court counterclaims, Calvert filed a federal action seeking damages under Rule 10b-5, as well as damages under the state court counterclaims. Thus, the validity of the reinsurance pool agreement under Rule 10b-5 was at issue im both the state and federal actions. Potentially analogous land use cases are those where the federal plaintiff seeks damages on a taking theory for land use restramts that are the subject of contemporaneous litigation in the state courts. See, e.g., cases cited at notes 63-65 supra.

361. In Brillhart v. Excess Ins. Co., 316 U.S. 491 (1942), one of the authorities on which the Colorado River Court relied, plaintiff sought relief under the Federal Declaratory Judgment Act, which is inherently discretionary. 437 U.S. at 671 (Brennan, J., dissenting). 
If Colorado River applies to non-declaratory-judgment diversity cases without violating the Meredith rule, it can logically be extended to the proliferating use of section 1983 to federalize zoning controversies. ${ }^{362}$ While there will be plausible arguments for other forms of abstention in most situations where a federal section 1983 zoning case is contemporaneous with state court litigation mvolving tle same claim, the Colorado principle might be applied to obviate any necessity for a rigorous Pullman, Burford, or Younger analysis. Thus, even thougli the federal proceeding would not be disruptive in the Burford sense, and even if the state law is relatively clear and does not involve the vimdication of important state interests, the federal court miglit invoke Colorado River to stay or dismiss the federal suit. ${ }^{363}$

The federal courts should exercise Colorado River abstention whenever an independent policy implicit in the relevant statute can be identified to counterbalance the general obligation to exercise jurisdiction. ${ }^{364}$ One source of such policy should emerge froin the rules that govern removal of cases to the federal courts. ${ }^{365}$ Where a federal plaintiff initiates suit in response to a removable pending state suit in which he is a defendant, a stay or dismissal of the federal suit may be justified to avoid duplicative litigation and to protect the integrity of time limitations on removal petitions. ${ }^{366}$ If the federal plaintiff wanted a federal forum he should have filed a timely removal petition rather than a separate suit. However, a section 1983 concurrent jurisdiction land use case will seldom invoke this scenario. The state defendant would usually not be able to remove the case to federal court because the state plaintiff's case probably would not be premised on a federal right. More typically, the federal plaintiff seeks to derail nonremovable state court land use litigation by commencing a federal suit premised on a violation of his civil rights. ${ }^{367}$

362. See, e.g., Finch v. Mississippi State Medical Ass'n, 585 F.2d 765 (5th Cir. 1978); $c f$. Utah Int'l Inc. v. Intake Water Co., 484 F. Supp. 36, 46 (D. Mont. 1979) (Burford and Colorado River abstention ordered in case involving contcmporaneous jurisdiction over a dispute arising under an interstate water compact).

363. The Calvert plurahity suggested that federal courts have greater latitude in extending the principles of Colorado River when they stay a case rather than dismiss it. 437 U.S. at 664-65.

364. See Bartels, Avoiding a Comity of Errors: A Model for Adjudicating Federal Civil Rights Suits that "Interfere" with State Civil Proceedings, 29 STAN. L. REv. 27, $80-81$ (1976); Comment, supra note 339, at 670 .

365. See generally 28 U.S.C. $\$ 1441$ (1976). The perception that reinovability rules reflect basic congressional poticy regarding the appropriate scope of federal jurisdiction is not new. $C f$. H. FRIENDLY, FEDERAL JURISDICTION 12-13 (1973) (illustrating a maximum inodel of jurisdiction by positing elimination of existing limits on renoval).

366. See Note, Stays of Federal Proceedings in Deference to Concurrently Pending State Court Suits, 60 Colum. L. REv. 684, 704 n.138 (1960).

367. Although decided before Colorado River, Creel v. City of Atlanta, 399 F.2d 777 (5th Cir. 1968), is a classic example of the Colorado River principle in a federal question context. Plaintiff, 
In such cases, the rule that precludes removability by a state defendant based solely on his ability to raise a defense grounded in federal $\mathrm{law}^{368}$ can be seen as the equivalent of the pohcy distilled from the McCarran Act that justified deference to the state proceedings in Colorado River. ${ }^{369}$ In both situations there is arguably a strong inference that Congress did not regard federal court resolution of the controversy as necessarily desirable. To similar effect is the rule that precludes removal based on a federally grounded counterclaim, ${ }^{370}$ to which an analogous case for deference to the state proceeding might be made. ${ }^{371}$ In both cases the rationale for Colorado River abstention is strengthened because the litigants should not be allowed to obtain jurisdiction by filing a separate action if they are unable to obtain it by seeking removal of a single consolidated action. Alternatively, if a state defendant initiates an independent federal suit in the hope that the federal court will exercise pendent jurisdiction over the entire controversy, the existence of a pending state proceeding might simply be treated as a factor in favor of the trial court exercising its discretion to disiniss pendent state claims ${ }^{372}$ without staying or dismissing the entire federal proceeding.

\section{CONCLUSION}

Land use controversies do not belong im federal court. Most plaintiffs who meet the jurisdictional prerequisites should lose on the merits of the federal constitutional claims. Thus, plamtiffs in most cases should seek relief in state courts, which can invahidate local regulatory actions as ultra vires or unconstitutional on either state or federal grounds. The supposed advantages of litigating these types of claims in the federal courts are counterbalanced by the reality of inevitable rough going on the merits in most cases.

More important, plaintiffs, as a tactical natter, should bring suit in

an owner of real estate adjacent to the Atlanta airport, brought an action under 28 U.S.C. \$ 1331, arguing that overflight constitnted an unconstitutional taking. At the same time, there was pending in the Georgia courts an action by the city to condemn the plaintiff's property. Even though neither injunctive nor declaratory relief was requested, the Fifth Circuit ordered the trial court to stay the federal proceeding in order to avoid the practical problems that would result if both proceedings went to judgment.

368. See, e.g., Bailey v. Logan Square Typographers, Inc., 441 F.2d 47, $51-52$ (7th Cir. 1971).

369. See Bartels, supra note 364 , at $80-81$.

370. Neither party can remove the defendant's constitntional counterclaim. 28 U.S.C. $\$ 1441$ (1976) limits removal to defendants and the connterclaim is apparently not treated as the relevant "civil action" for purposes of $\$ 1441$ (a). See Shamrock Oil \& Gas Corp. v. Sheets, 313 U.S. 100, 107 (1941).

371. The rationale for this latter rule is said to be prevention of the abuse of filing a marginally colorable counterclaim in the state court solely in order to remove. Note, supra note 364 , at 670 .

372. United Mine Workers v. Gibbs, 383 U.S. 715, 726 (1966). 
state court because in inost land use controversies the federal courts can avoid considering the merits of plaimtiffs' claims. Available local administrative reinedies may have to be exhausted. Pullman abstention requires the federal courts to postpone jurisdiction to resolve federal constitutional issues until state courts decide unsettled state law issues. If the state law issues involve transcendent state programs, the broader federalism concerns of Burford abstention should require the federal court to dismiss the case, thus avoiding federal interference with important state policies. In cases where a related state action is pending before proceedings of substance have begun in the federal forum, the federalism and comity concerns of Younger abstention or the judicial econoiny concerns of Colorado River abstention should mandate dismissal also.

Thus, for land use controversies it can no longer be readily assumed that jurisdiction colorably conferred on a federal court is jurisdiction that must be exercised. Examination of the recent developments in abstention law suggests that regardless of the basis of jurisdiction, almost all federal land use cases lend themselves to the application of at least one, and often more, of these complex but related access-limiting doctrines. 